\title{
Genforeningen og De Danske Statsbaner i Sønderjylland 1918-1928
}

\author{
af Ole Nørregaard Pedersen
}

Nordslesvigs genforening med Danmark i 1920 betød for De Danske Statsbaner et nyt arbejdsområde. Overtagelsen af de preussiske statsbaner syd for Kongeåen krævede omfattende forberedelser. Et centralt spørgsmål var, hvor den nye store grænsestation til erstatning for Vamdrup station skulle placeres. Fra første færd stod det ikke klart, at den lille og ubetydelige station "Paddeborg « skulle være grænsestation, placeret direkte på landegrænsen. På baggrund af kilder i Danmarks Jernbanemuseum i Odense beretter pens. trafikinspektør Ole Norregaard Pedersen, Odense, her om De Danske Statsbaners første etablering i Senderjylland

\section{Planlægning af overtagelsen}

Meget tidligt efter afslutningen af 1. Verdenskrig må De Danske Statsbaner være gået i gang med en omfattende planlægning før overtagelsen af banerne i Nordslesvig. Allerede den 7. marts 1919 beskæftiger dagspressen sig med spørgsmålet. Den dag skriver "Københavns Amts Avis", at statsbanernes Generaldirektion har påbegyndt overvejelser angående overtagelsen af de forskellige sønderjyske baner. Avisen forudser betydelige vanskeligheder. I 1919 hersker der i Danmark en udbredt mangel på stort set alt, som er nødvendigt for at kunne løse opgaven. Der er mangel på personale og materiel og ikke mindst kul. Især savner man konkret kendskab til opgavens tekniske og økonomiske omfang. Derfor kan det heller ikke overraske, at spørgsmålet: "Har vi råd til det? - hvad kommer det til at koste? « blev rejst allerede først på året 1919.

»Det midlertidige Ministerium for sønderjyske Anliggender« bad på samme tid statsbanerne beregne værdien af de aktuelle jernbanestrækninger. Det må tolkes derhen, at ministeriet ventede, at den forestående indlemmelse af de sønderjyske landsdele i kongeriget ville indebære en større økonomisk »slut-opgørelse« over mellemværendet 
mellem de to lande, Danmark og Tyskland. Hvad var banerne værd? Hvordan greb statsbanerne nu denne opgave an?

Statsbanerne inddelte det sønderjyske banenet i tre zoner. Den første gik fra Vamdrup til linien Padborg-Sønderaa. Her startede 2. zone, som gik ned til en linie gennem Husby station $-3 \mathrm{~km}$ syd for »Borderup station « til $4 \mathrm{~km}$ syd for Langhorn. Den tredje zone gik herfra til Slien. Inddelingen refererer til et mødereferat i Generaldirektoratet den 27. marts 1919, journ. 1919/581 N3. Sagsbehandleren har tilsyneladende ikke været helt fortrolig med topografi og korrekte stednavne. "Borderup station« må være »Barderup Trinbræt« lige nord for Tarp, og "Langhorn station « er en lokalitet lidt nord for Bredsted, det vestligste punkt i en tænkt grænsedragning ca. $15 \mathrm{~km}$ syd for Flensborg.

I sit svar til ministeriet måtte statsbanerne bygge på et skøn. Også fordi man helt manglede konkrete informationer og fagteknisk kendskab til de aktuelle strækninger og disses udstyr. Resultatet var, at skønnet udelukkende blev baseret på danske normer og standarder for lignende strækninger og med en vedligeholdelsesstandard ført op til tidssvarende dansk. I sit svar til "Det Midlertidige Ministerium«, når statsbanerne frem til følgende skøn over de sønderjyske strækningers værdier:

banerne i første zone

banerne i første og anden zone alle 3 zoner samlet
15,5 mio. $\mathrm{kr}$.

23,5 mio. $\mathrm{kr}$.

31,5 mio. $\mathrm{kr}$.

Den 23. marts 1920 vender ministeriet tilbage til spørgsmålet og anmoder nu statsbanerne om senest inden 10 dage at foretage en ny, specificeret vurdering af de Preussiske Statsbaner i den første zone, incl. tilhørende bygningsmasser, opgjort pr. 1. august 1914. Opgørelsen skal tage hensyn til senere værdiforringelser grundet overdreven slitage og manglende vedligeholdelse. Ministeriet påpeger, at det er af betydning, af hensyn til fredstraktatens bestemmelser, at det kan konstateres, hvorvidt de pågældende aktiver er tilvejebragt ved tyske (preussiske) statslån eller ved løbende indtægter.

I denne tidsmæssige heksekedel omkring marts/april 1920 i Danmark med meget urolige indenrigspolitiske forhold, med dens "Påskekrise", trussel om generalstrejke, to midlertidige forretningsministerier, og den forestående nedlæggelse af »Det midlertidige Ministe- 


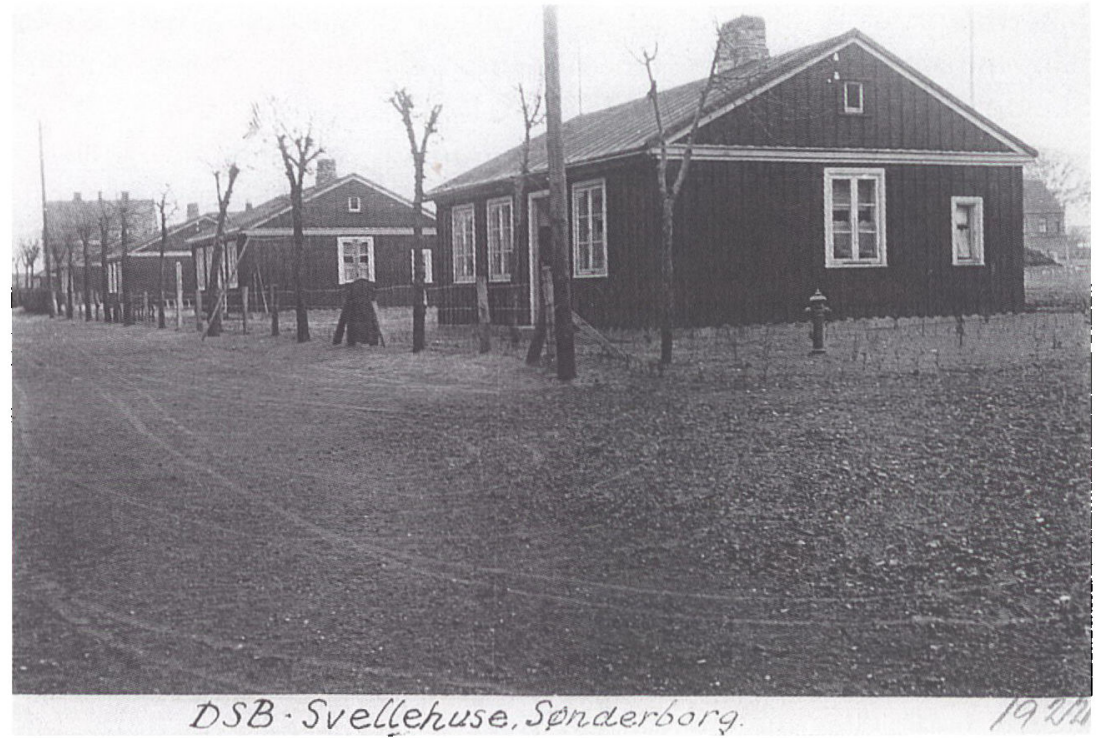

For at afhjælpe den katastrofale mangel på boliger til de udsendte jernbanefolk $i$ Sonderjylland efter Genforeningen - og for overhovedet at skaffe tag over hovedet, opforte Statsbanerne en rakke "midlertidige tjenesteboliger" rundt om $i$ landsdelen. Her ses »boliggaden" $i$ Sonderborg. Foto $i$ Jernbanemuseet.

rium for Sønderjylland ", svarer statsbanernes generaldirektør Theodor Andersen Alstrup den 7. april 1920:

- at det økonomiske skøn over de Preussiske Statsbaners aktiver i den første zone må nedsættes til 13 mio. kr. Samtidig gør generaldirektøren opmærksom på, at der kun kan være tale om et ganske skønsmæssigt overslag. Hvis et ministeriums normale praksis skulle efterleves, ville det kræve en ekspeditionstid på to måneder at udfærdige et svar!

For statsbanernes øverste ledelse var det også vitalt snarest at få opbygget en lokal sønderjysk ledelsesorganisation til at varetage drift, anlæg og tilsyn for den kommende sønderjyske jernbanedrift. Som nord for Kongeåen kom den decentrale ledelsesorganisation til at hvile på et antal faglige "sektioner«, placeret i Tønder og Aabenraa.

I Aabenraa placeredes 10. Trafiksektion, ledet af en trafikinspektør og 15. Banesektion, ledet af en baneingeniør, støttet af en telegrafmester. I Tønder placeredes 11. Trafiksektion med sin trafikinspektør og 16. Banesektion, også ledet af en baneingeniør. Hele Sønderjyllands lokomotiv- og materieltjeneste koncentreredes ligeledes $\mathrm{i}$ Tønder ved 
placeringen af 6. Maskinsektion ledet af en maskiningeniør. Under ham maskindepoter i Tønder, Aabenraa, Haderslev, Vojens, Tinglev, Skelde og Sønderborg. Denne nye ledelsesorganisation stattedes yderligere ved udnævnelse af 4 overbanemestre, som fik tjeneste i Vojens, Tinglev, Tønder og Tørsbøl. Hele organisationens nærmeste overordnede driftsledelse blev statsbanernes 2. Distrikt i Aarhus hhv.

3. Distrikt i Struer.

For hurtigst muligt at fremskaffe konkrete informationer om forholdene i Sønderjylland blev der fra begyndelsen af 1919 og frem til afstemningen i 1 . Zone, den 10. februar 1920, gennemført en række statsbane-aktiviteter i landsdelen. Personaleorganisationen "Jernbaneforeningen «, som repræsenterede »Guldsnorene« (embedsklasserne), hvorfra Sønderjyllands nye stationschefer skulle rekrutteres, iværksatte den 5. april 1919 en foreløbig undersøgelse i landsdelen. Formålet var at skaffe grundlaget til en foreløbig medlemsorientering om alle relevante forhold som fysiske anlæg, byernes indbyggerantal, eksisterende eller manglende eksistens af tjenesteboliger, mulighed for at leje private boliger, antal medarbejdere på den enkelte station og dennes udstyr o.s.v. Undersøgelsens resultat rundsendtes til medlemmerne, inden disse fattede pen og blæk til ansøgningen om sønderjyske stillinger. Spørgsmålet: »Udsigt til at få lejlighed « blev, stort set for alle pladsers vedkommende, besvaret med et klart: »Nej«.

\section{Ansøgninger}

Denne meget tidlige aktivitet havde baggrund $i$, at "Guldsnorene« måtte forvente, at statsbanerne meget snart ville indkalde ansøgninger til de nye stillinger i Sønderjylland, som ville blive ledige, når de preussiske chefer og ledere forlod landsdelen.

Situationen forelå allerede den 30. marts 1919. Den dag tog statsbanerne hul på spørgsmålet om den fremtidige bemanding af Sønderjylland. I en strengt fortrolig skrivelse fra Generaldirektoratet til 1., 2. og 3. Distrikt blev disse bedt om at indkalde ansøgninger fra interesserede, primært til chef- og lederstillinger på de forventede overtagne stationer. I første omgang drejede det sig om ca. 100 mand.

En af ansøgerne var den senere regnskabsfører C. Schmidt i statsbanernes 1. Distrikt. I "Dansk Jernbaneblad" fra 19. august 1942, fortæller han, at han meldte sig som supplikant hos generaldirektor Th. Andersen Alstrup til ledige stillinger i Sønderjylland. Her skal han være 
modtaget noget forbeholdent med de ord, at dem, man ville udvælge til Sønderjylland, skulle være en slags »Missionærer«: de skulle hellige sig embedet og gennem en neutral holdning i nationalpolitiske spørgsmål gøre sig værdige til den samlede lokalbefolknings agtelse og tillid.

For yderligere at klargøre situationen for ansøgere, og for at få eksisterende sønderjyske informationer ført à jour, sendte »Jernbaneforeningen « sin næstformand på en studietur til 1. afstemningszone. Turen fandt sted i dagene 26. til 31. januar 1920. Næstformanden, trafikassistent Høgsgaard, gennemrejste strækningerne VamdrupHarreslev-Tønder-Højer-Skærbæk-Løgumkloster. Hans rapport, eller opgørelse, over rejsen er en grundig beskrivelse af den enkelte besøgte station, lige fra bygninger til sporanlæg med ramper, kanonramper, signal- og telegrafudstyr, brovægte, tilslutning til privatbaner og postarbejdets omfang.

Det måske mest interessante element i Høgsgaards udførlige rapport er, at han gav en udførlig beskrivelse af Faarehus (sådan lød navnet til 1924) og Harreslev stationer, men helt har udeladt den lille og ubetydelige station »Paddeborg «. Det tyder på, at den erfarne drifts- og organisationsmand har vurderet, at lokaliteten "Paddeborg" fysisk og terrænmæssigt var uinteressant, og måske måtte lades helt ude af betragtning som Danmarks nye, store grænsestation på den kommende landegrænse. Hans beskrivelse mangler desværre argumentation for denne opfattelse.

Straks efter at resultatet af afstemningen i 1. Zone den 10. februar 1920 var offentliggjort, tog statsbanernes øverste ledelse på en række tjeneste-, besøgs- og studierejser i landsdelen.

Det begyndte med generaldirektør Th. Andersen Alstrup, der umiddelbart efter tog afsted for at træffe egnens ledende personligheder og gøre sig bekendt med statsbanernes nye administration. Herefter var det vigtigt, at også generaldirektørens nærmeste fagmedarbejdere, afdelingscheferne i generaldirektoratet, snarest ved selvsyn gennem besøg på stedet skaffede sig et detaljeret kendskab til de preussiske statsbanestrækninger, som De Danske Statsbaner forventedes at overtage. Samtidig fik disse centrale embedsmænd på højt niveau lejlighed til at opbygge personlige relationer og netværk i Sønderjylland.

Forud for disse officielle rejser blev alle formaliteter overholdt, og der blev indhentet tilladelser og samtykke til rejsernes gennemførelse 
i »Den Internationale Kommission « og hos de preussiske statsbaner i Flensborg.

For afdelingscheferne blev turen en større rundrejse i automobil i dagene fra den 22. til den 26. februar 1920. Alle sønderjyske købstadsog knudestationer samt så mange landstationer som muligt blev besogt.

Jernbanemuseets arkiv rummer kopi af chefernes udførlige afrapportering til generaldirektøren. De besøgte stationer beskrives alle meget detaljeret, og der er supplerende oplysninger om medarbejderne de enkelte steder. Blandt andet observeredes en meget ringe arbejdsiver blandt personalet.

Chefkredsen beskæftigede sig også med de lokale chefers og lederes nationale sindelag. De skriver, at bortset fra Clemmesen i Padborg, så fandtes der kun een dansksindet, nemlig Poulsen i Bolderslev. Sidstnævnte overgik i 1920 uden videre til De Danske Statsbaner som stationsmester i Bolderslev.

Usædvanligt for alle besøgende var det at finde, at en del tekniske anlæg, som f.eks. side- og enderamper, var meget større og oprindelig kostbarere udført end på tilsvarende stationer i Danmark. Således fandtes på stationerne i Bredebro og Skærbæk lange militærramper med vedliggende spor og udtræksspor i begge ender, øjensynligt bestemt til hurtig udladning af et rytterregiment. Tilsvarende var krydsningssporene flere steder endog meget lange. Især på strækningen Hvidding-Tønder-Tinglev betydeligt længere end til almindeligt civilt behov. En infrastruktur klart etableret af militære årsager og typisk for opmarchområder.

\section{De Danske Statsbaner udpeger nye chefer og ledere}

Som første og væsentligste led i løsningen af bemandingsspørgsmålet udvalgte statsbanerne i efteråret 1919 de kommende chefer og ledere til Sønderjyllands nye trafik-, bane- og maskinsektioner samt overbanemestre og en telegrafmester.

Som chef for den nyetablerede 10. Trafiksektion i Aabenraa udnævntes trafikinspektør E. A. G. V. Juel-Hansen. Han kom fra 1. Distrikts Trafiktjeneste $\mathrm{i}$ København og fik som ansvarsområde strækningerne Vamdrup - ny grænse, Haderslev- og Aabenraabanen, Tinglev-Sønderborg og Tørsbøl-Padborg samt Vester Sottrup-Skelde.

Fra Randers hentedes trafikkontrollør A. J. Joest som chef for 11. 
Trafikinspektor

A. J. Joest, 11. Trafiksektion, Tonder, f. 1866. Frem til 1920 gjorde Joest tieneste $i$ Viborg, Aarhus, Langaa, Hjørring, Randers og på Kobenhavns Godsbanegaard. Ved Genforeningen blev Joest forfremmet fra Randers til trafikinspektor og chef for den nyetablerede 11. Trafiksektion $i$ Tonder. Da denne sektion af sparehensyn blev nedlagt $i$ slutningen af 1924 , hentedes han i februar 1925 til ny chef for 10 . Trafiksektion $i$ Aabenraa som efterfolger for JuelHansen. Foto $i$ Jernbanemuseet.

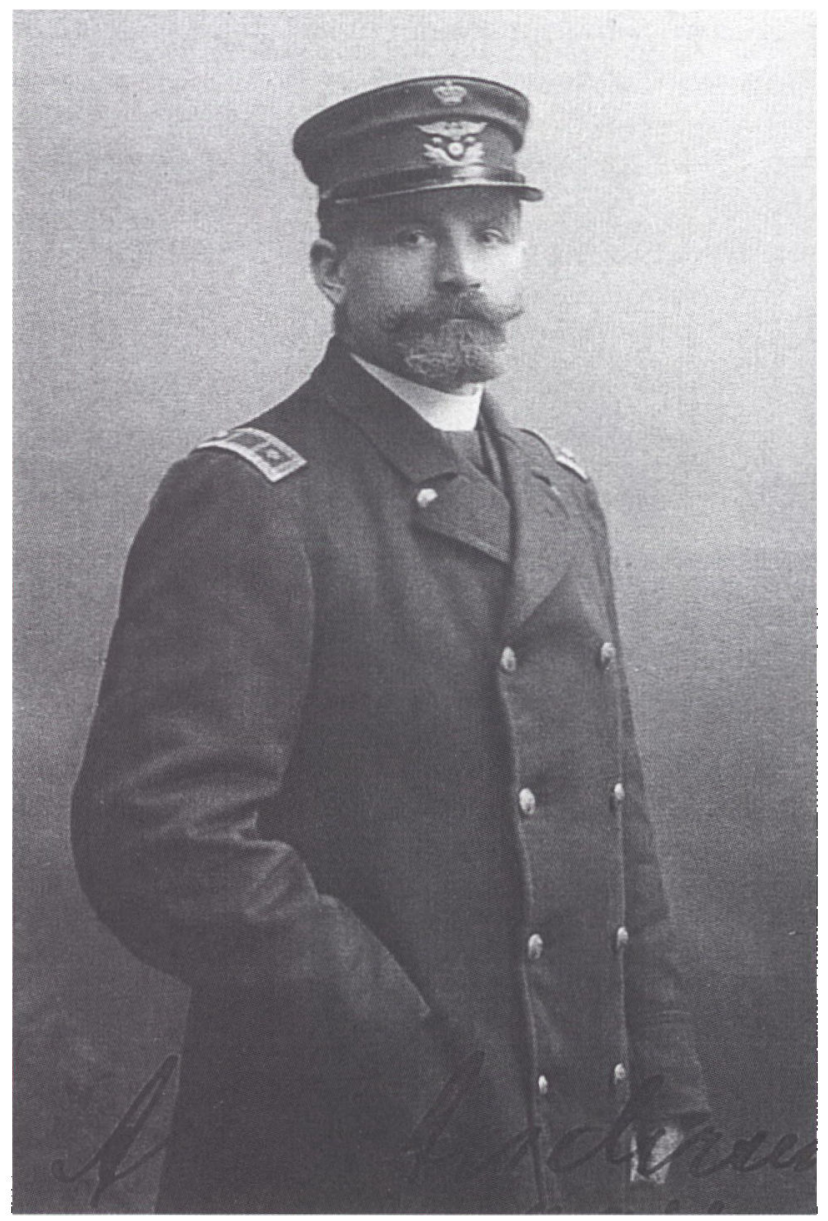

Trafiksektion i Tønder, også med charge af trafikinspektør. Hans ansvarsområde blev resten af de preussiske statsbaner i Sønderjylland, primært i landsdelens vestlige del.

Baneingeniørerne til Aabenraa og Tønder kom fra Herning og København. Overbanemestrene forflyttedes/forfremmedes fra hele Jylland, nemlig fra Frederikshavn, Randers og Skjern.

Hurtigt fulgte udpegningen af ca. 50 stationsforstandere og stationsmestre. Samtlige blev hentet fra alle kroge af »det gamle land « nord for Kongeåen. Derfor blev de sønderjyske statsbanestationer, 
bortset fra stationsmesteren i Bolderslev, på ledelsesplan alle befolket med "Rigsdanske".

Udpegningen af den enkelte skete umiddelbart efter afstemningen den 10. februar 1920. Hver især havde fået en foreløbig orientering om udpegningen med ordre til at være klar, med ganske kort varsel, til hurtig afrejse til Sønderjylland.

De følgende år skulle vise, at statsbanerne med personvalgene havde en heldig hånd. Jernbanemuseets kilder fra 1919 og tiden derefter er især righoldige hvad angår chefen for 10. Trafiksektion i Aabenraa, trafikinspektør Juel-Hansen. Hans embedsområde omfattede de fleste af Sønderjyllands vigtigste byer med tilsyn og ledelse af driften på den østlige hovedbane fra Vamdrup til den nye grænse, hvor han også måtte forestå opbygning og anlæg af alle nødvendige statsbane-faciliteter til en ny, stor dansk grænsestation, så at sige på bar mark, hvor grundejerne og lokalbefolkningen overvejende var tysksindede.

Juel-Hansens medarbejdere i sektionen har senere beskrevet chefen som: »ikke noget hverdagsmenneske«. Han var bredt vidende, udadvendt, intelligent, charmerende og samtidig en fornøjelig fortæller kort og godt foruden sin faglige kunnen også et stort selskabsmenneske - ikke for ingenting nevø af digteren Holger Drachmann og søn af forfatterinden Erna Juel-Hansen.

Fra arkiverne opleves Juel-Hansen som en diplomatisk personlighed med gode relationer til magt- og ledelsesorganerne i Aarhus og København.

Souschefstillingen hos Juel-Hansen blev besat med en helt anden mennesketype. Det blev trafikkontrollør C. C. Christensen fra Esbjerg. Han kom til sektionen fra en stor, travl jernbanestation og havde betydelig drifts- og administrativ erfaring. C. C. Christensen var af profil mere tung i det, let bekymret, men en yderst solid og omhyggelig arbejdskraft, der praktiserede den skønneste håndskrift - ja sligt havde sin store betydning - også dengang. De to må have udgjort et næsten perfekt ledelsesteam.

Hvad var mere naturligt, end at Juel-Hansen, straks efter ankomsten til Aabenraa i 1919, flyttede ind på "Folkehjem " med såvel sit tjenestekontor som sin private bolig.

Det var naturligvis kun en rent midlertidig løsning på trafiksektionens samlede lokalebehov. Statsbanerne måtte hurtigt skaffe sin administration i Aabenraa et mere permanent domicil med tilfreds- 
Trafikinspektor

E. A. G. V. Juel-Hansen, 10. Trafiksektion, f. 1878. Efter ansattelse ved statsbanerne 1890-97 laste JuelHansen til studentereksamen og tog derpå polyteknisk embedseksamen. I 1916 blev han udnawnt til trafikinspektor $i$ 1. Distrikt $i$ Kobenhavn. Herfra udpegedes han $i 1919$ til chef for den nyetablerede 10. Trafiksektion, som efter en tid blev placeret $i$ Aabenraa by. I foråret 1925 forflyttedes JuelHansen til en nyoprettet stilling under statsbanemes trafikchef $i$ Kabenhaun og blev derefter sporvejsdirektor $i$ Kobenhavn. Foto $i$ Jernbanemuseet.

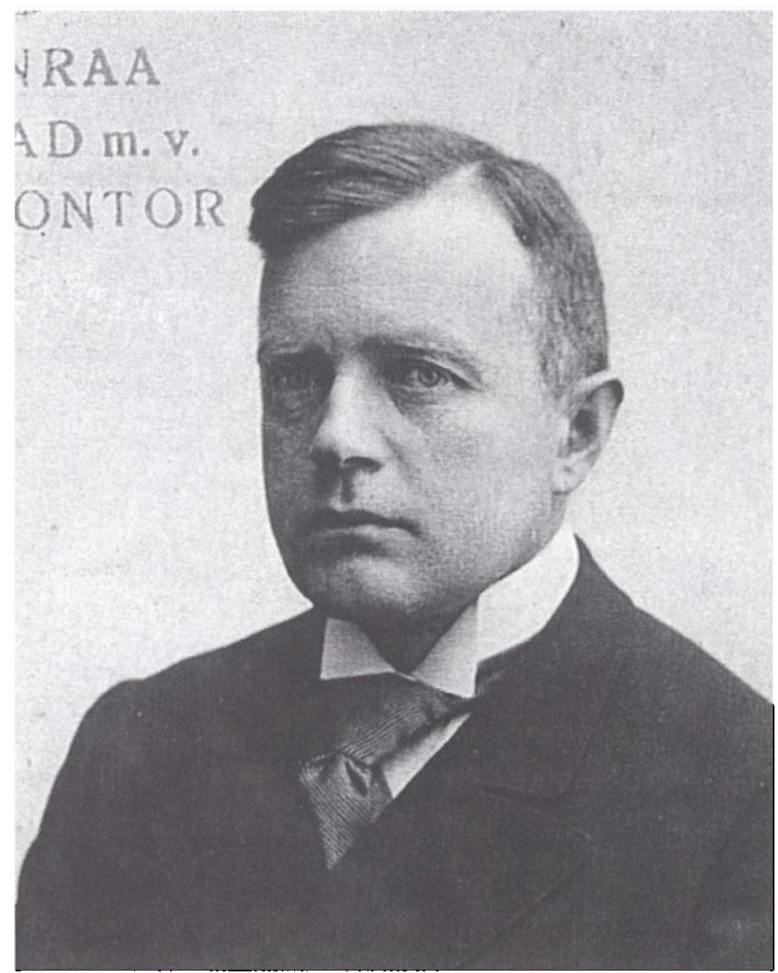

stillende lokale- og arbejdsforhold i passende rammer. Løsningen blev køb af ejendommen Store Pottergade nr. 6 i det indre af Aabenraa by. Ved tinglyst skøde af 30 . oktober 1920 blev statsbanerne ejer af bygningen, som var en større velbygget og repræsentativ rødstens etageejendom, der værdigt signalerede tillid og troværdighed. Statsbanerne ejede og anvendte ejendommen til marts 1933, hvorefter den blev solgt til den nye "Sygekasse for Aabenraa By".

Næste store opgave for de to trafikinspektører Juel-Hansen og Joest blev at samle de udpegede stationschefer og ledere til en aktuel orientering om den seneste udvikling i Sønderjylland. Orienteringsmødet fandt sted den 13. marts 1920 på "Søpavillonen « i København. Her lød beskeden på, at alle måtte forvente, på en senere udpeget dato, at skulle indfinde sig på perronen i Vamdrup efter ankomsten af eftermiddagstoget fra nord. Her ville alle få "allerseneste“ nyt. Alle blev instrueret om ved ankomsten at være forsynet med gyldigt dansk pas, 


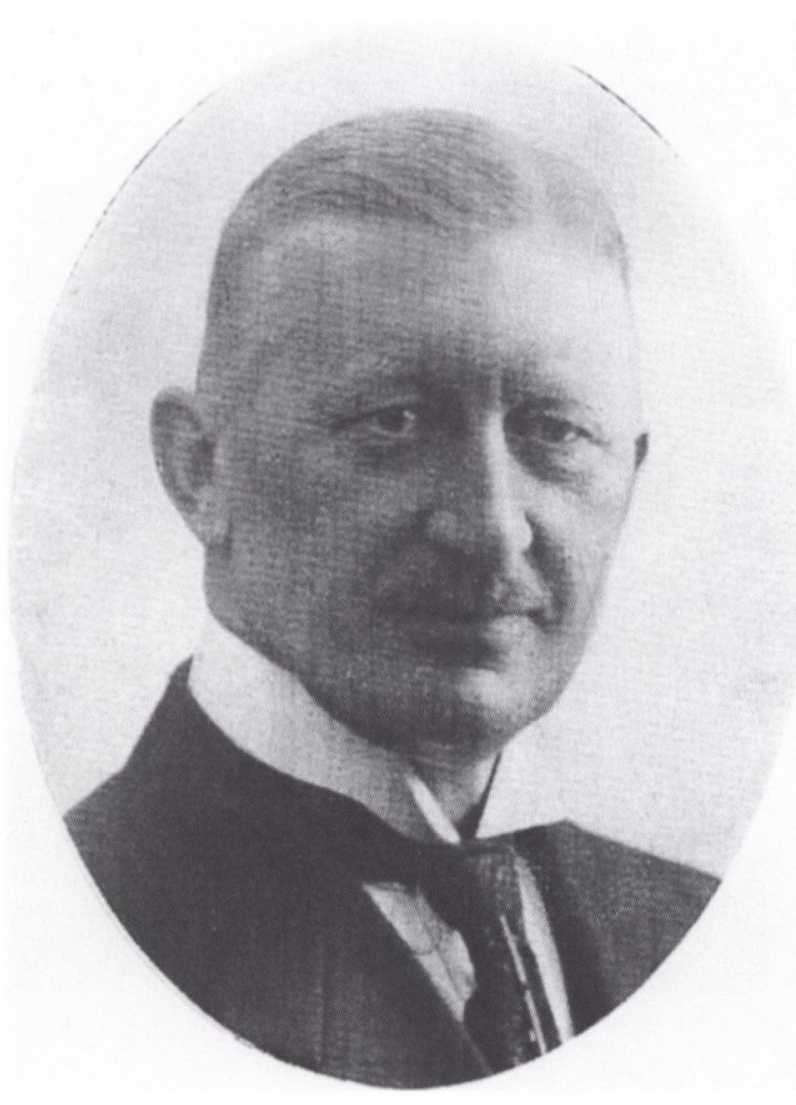

Stationsforstander G. G. Ulrich, Tender, f. 1868. Efter tjeneste mange forskellige steder blev han udnæont til godsekspeditor $i$ Slagelse den 1. februar 1915. Herfra hentedes

G. G. Ulrich ved Genforeningen $i$ 1920 til stillingen som stationsforstander $i$ Tonder. Som embedsmand var han en person med rige eoner, der overlegent beherskede alle grene af jernbanetjenesten. I Tonder loste han den vanskelige opgave dygtigt og vardigt og vandt hele befolkningens agtelse og tillid. Ulrich blev $i$ embedet indtil pensioneringen 1933. Foto Jernbanemuseet.

ny uniform og have købt gyldig billet fra Vamdrup til den udpegede "preussiske statsbanestation " syd for Kongeåen.

Med hensyn til den enkeltes menneskelige fremtræeden, attitude og optræden, henvistes til generaldirektør Andersen Alstrups påbud om at »være som missionæren«, og at alle, på det udpegede tjenestested, skulle forholde sig neutralt og dygtiggøre sig på stedet til overtagelsen. Kort sagt - alle skulle holde lav profil - suge til sig af de holdninger, traditioner og kulturer, der rådede på hvert sted og egn. I alle nationale spørgsmål skulle der optrædes efter devisen: "Ich bin Beamter - Ich habe keine Meinung".

At formaningen var på sin plads og blev efterlevet, beretter den nyudpegede stationsforstander Wissenbach: "Nogen tid før nedrejsen fik jeg en henvendelse fra formanden for den danske forening i Ting- 
lev med anmodning om at meddele foreningen hvilken dag og klokkeslæt, jeg kom til Tinglev, da foreningen ville modtage byens første danske stationsforstander festligt på perronen.

Anmodningen blev ikke efterkommet af mig. Der var ingen grund til udæskning eller demonstration.

Nogle dage senere, efter at Berlin havde givet tilladelse til at flage med Dannebrog fra private bygninger, arrangerede foreningens formand dagen efter flagallé gennem Tinglev for på den måde at fejre stationsforstanderen« (kilde: »Vor Stand « nr. 4 af 25.11.1955.).

\section{Mandskabets udsendelse}

Sidst i marts 1920, få dage efter informationsmødet i København, fordeltes tjenstligt de endelige rejseordrer til den enkelte. Alle skulle møde $\mathrm{i}$ Vamdrup med middagstoget den 21. april til vidererejse ind $\mathrm{i}$ det ukendte.

I Vamdrup blev alle modtaget af Juel-Hansen, der gav en kortfattet instruktion, og endte med at gentage rådet om, at alle $\mathrm{i}$ den daglige færden dernede burde handle ud fra ordene: „Ich bin Beamter, Ich habe keine Meinung".

Med nyindkøbt gyldig preussisk billet $\mathrm{i}$ hånden drog nu en større gruppe sydpå, hvor den enkelte snarest, efter ankomst til sin bestemmelsesstation, skulle melde sig i »tiltrædelsesaudiens « hos den stedlige preussiske kollega. Her skulle den nyankomne danske embedsmand indtil videre leve tjenstligt med de preussiske kolleger, som $i$ forste omgang ikke skulle afgive nogen form for myndighed eller kompetence. Det skete først ved den endelige overtagelse mere end to måneder senere.

Arkiverne beretter om, at modtagelsen kunne få et forskelligt forløb. I Haderslev gjorde ovennævnte C. Schmidt sammen med den nyudpegede danske stationsforstander J. J. Høgdal og godsekspeditør A. V. Kaaber en sen aften deres entré på stationen, hvor alle blev modtaget korrekt af den preussiske stationsforstander Rademacher, med hvem danskerne de næste to måneder havde den bedste omgang, præget af korrekthed og venlighed. Det gjaldt også for det øvrige preussiske personale.

Danskerne så straks, at fire års verdenskrig havde sat præg på stationen. Modtagelsen foregik på Rademachers kontor, hvor han stram og militærisk i sin uniform stod ved en faldefærdig pult og arbejdede 


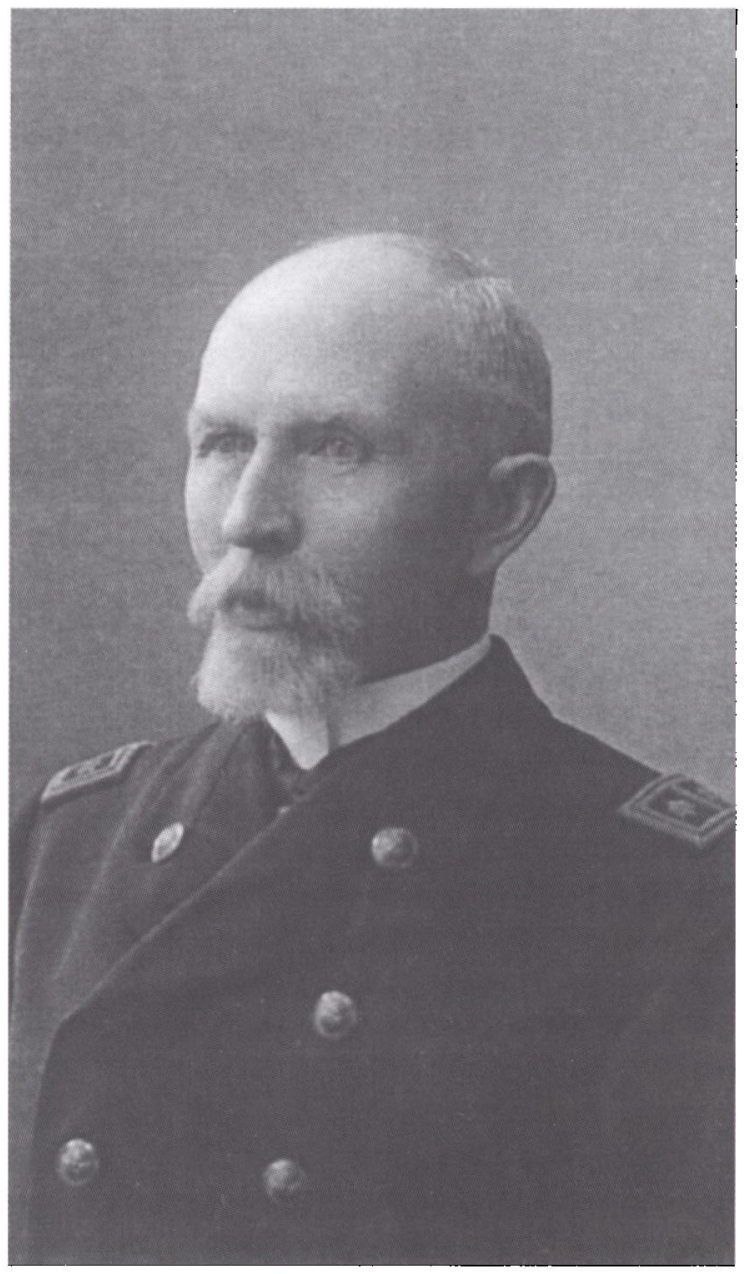

Stationsforstander Jens Jensen Hogdal, Haderslev, $f .1860$. Efter tjeneste mange steder $i$ landet blev han forfremmet til stationsforstander $i$ Vedsted fra 1. december 1914. Ved Genforeningen stationsforstander $i$ Haderslev. Der er ingen tvivl om, at J. J. Hogdal drog til Haderslev med store dromme, isæer om nyanlag af den forventede sonderjyske kystbane fra Kolding over Haderslev og Aabenraa til Flensborg. Tanken havde varet oppe fra såvel tysk som dansk side, og ihvertfald forventede sonderjyske kredse, at den danske stat ville realisere planen efter Genforeningen. I så fald ville Haderslev station blive en betydelig trafikstation pà hojde med Vejle og Horsens. Da tanken måtte opgizes, lod J. J. Hogdal sig $i$ 1922 forflytte til Frederikssund. Foto i Jernbanemuseet.

ved det sparsomme lys fra en gammel, snavset og sodet olielampe. Det var svært for de danske at fatte, at de befandt sig i et offentligt kontor. Det mindede snarere om et forfaldent smedeværksted; loft og vægge med løse kalkflader, alt sodet og tilrøget. Gulvet var som i et støberi; varmekilden var en rustrød kakkelovn, revnet og sammenbundet med ståltråd. Hele bygningen viste sig forøvrigt at være undermineret af svamp, rotter og mus. Rengøringen blev derfor helt illusorisk. Den blev varetaget af en dame for 36 Mark pr. måned eller efter kursen i april 1920 ca. 3 kr i danske penge. 
En helt anden situation oplevede den nyudpegede danske stationsforstander i Tinglev, J. A. Wissenbach, som kom fra Esbjerg. I sine personlige erindringer skriver han, at de udsendte følte sig som emigranter, der drager ud mod det nye og uvisse. Særlig de, der skulle længst sydpå - nær den fremtidige grænse - følte, at de ville blive stillet mellem to partier, hvor der fra det ene ville stråle hjertevarme og fra det andet iskulde mod dem.

Her bør det, for nutidens læsere, erindres, at Wissenbach kom til en by og en egn med et stort tysk befolkningsflertal, som alle håbede på, at den endelige grænsedragning ville blive baseret på den såkaldte "Tiedje-linie". Denne ville fastholde Tinglev og sogne rundt om under Tyskland. En sådan grænsedragning ville automatisk medføre, at Herr Wissenbach kunne forvente, i løbet af kort tid, at måtte returnere til nord for Kongeåen.

I forkortet form skriver Wissenbach videre: "Jeg mødte den 22. april 1920 om formiddagen på stationen for at aflægge min tyske kollega, Johs. Hansen, en visit. Af vagthavende tyske trafikassistent blev jeg straks mødt med den kolde skulder, idet beskeden fra stationsforstanderen lød: »Han kan ikke træffes foreløbig. Han er optaget i sin tjenestehave med at lægge sildige efterårskartofler«.

At Wissenbach oplevede en meget spændt atmosfære bekræftes også af, at han måtte låse det DSB Dannebrog, som var tilsendt til senere brug, inde i et jernpengeskab. Den til flaget hørende flagsnor havde han af sikkerhedsgrunde måttet anskaffe i form af en stålwire. I sandhedens navn må det medgives, at Tinglev station absolut var undtagelsen.

Forud for udsendelserne den 21. april havde de Preussiske Statsbaners Eisenbahndirection i Altona og Betriebsamt i Flensborg gjort meget ud af at informere og instruere stationerne om danskernes ankomst, tilstedeværelse og behandling. De lokale preussiske chefer med medarbejdere fulgte korrekt og loyalt ledelsens instruks. Så at sige overalt forløb overgangen og det jernbanefaglige samarbejde gnidningsløst og problemfrit. Alligevel følte de udsendte danske tjenestemænd sig som gæster og tilbragte de to måneders ventetid $i$ »dolce far niente«.

Selvom hovedparten af alle civile administrationsområder i de sønderjyske landsdele efterhånden overgik på danske hænder, og der kom danske hærstyrker fra den 5. maj, så forblev administrationen og ledelsen af jernbanerne på preussiske hænder. For de nyetablerede 


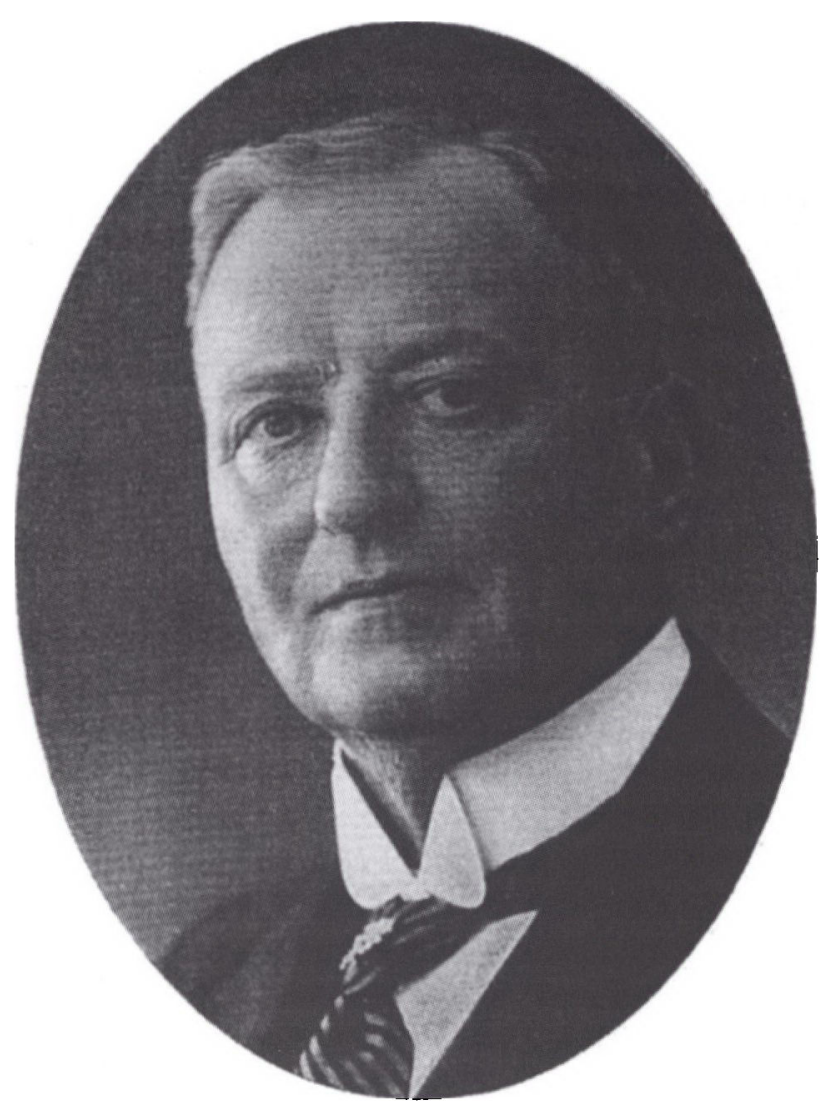

Stationsforstander J. A. Wissenbach, Tinglev station, f.1868. Ved Genforeningen blev han forfremmet $t i l$ stationsforstander $i$ Tinglev. 5 arr senere, den 1. december 1925, udnavnt til stationsforstander $i$ Esbjerg. Han var en meget dygtig og interesseret embedsmand, fyldt med humer og et lyst syn på tilværelsen. Foto Jernbanemuseet.

danske ledelsesorganer i Aabenraa og Tønder blev perioden fra nytår 1919/20 til den endelige overtagelse derfor turbulent, til tider ret så dramatisk.

\section{Afstemningstidens køreplaner}

Al togdrift baserer sig på køreplaner. Så tidligt som i foråret 1919 havde Generaldirektoratets Køreplanskontor været sat på opgaven. Det resulterede i den allerførste "Tjenestekøreplan for Sønderjylland «, som var klar den 12. juli 1919 - dog - uden konkret ibrugtagningsdato. En gennemarbejdet plan klar »i skuffen«, men pålagt ordren om, at »denne ikke måtte offentliggøres for publikum«. I forhold til den eksisterende preussiske køreplan for sommer/efterår 1919 bød dette 
Udkast til Statsbanernes allerforste koreplan for Sonderiylland dateret den 12. juli 1919. Jernbanemuseet.

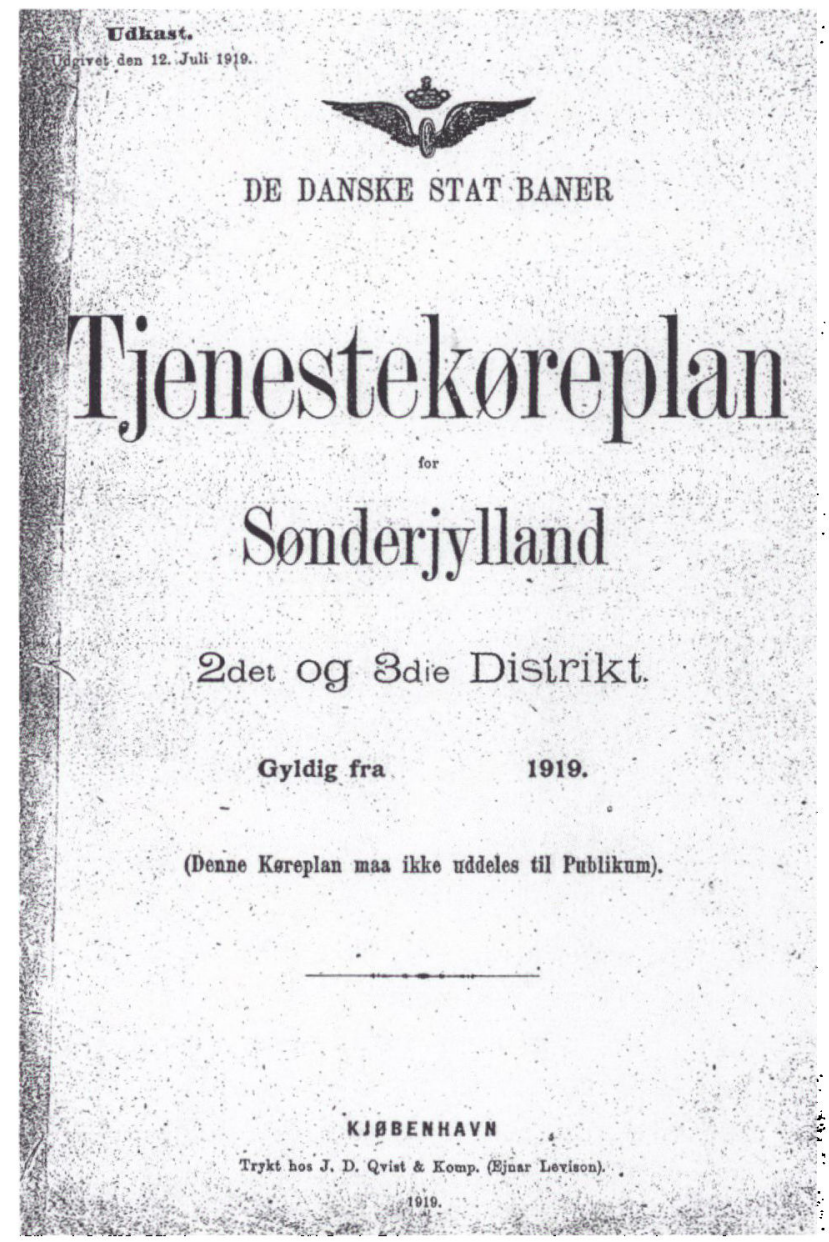

første danske udkast på væsentlige udvidelser af landsdelens rejsemuligheder.

Planen blev aldrig bragt i anvendelse. De eksisterende preussiske køreplaner forblev $\mathrm{i}$ kraft $\mathrm{i}$ hele overgangsperioden, indtil første danske plan blev sat i kraft fra og med den 1. juli 1920. Men da blev resultatet, som vi skal se nedenfor, ikke så lidt ringere end udkastet fra 1919.

Næste køreplansopgave blev at afvikle togtransporten for de danske stemmeberettigede til afstemningen i 1 . Zone. 
Til løsning af denne store, vigtige opgave blev der i dagene 27. og 28. januar 1920 afholdt et stort fællesmøde på »Hotel Flensburger Hof « i Flensborg. Det skete dagen efter, at »Den Internationale Kommission « var kommet til Flensborg med tog fra København.

På mødet aftaltes alle transportforanstaltninger for danske stemmeberettigede såvel med tog som skib. Ikke alene på det overordnede plan, men helt ned $i$ enkeltheder med angivelse af antal berettigede og deres destination. For statsbanerne drejede det sig om 13 ekstratog fra Vamdrup og seks ekstratog fra Vedsted fordelt på udrejse den 7., primært den 8. og 9. februar 1920. I alt ca. 8000 personer. Togene primært formeret af dansk personvognsmateriel og lokomotiver betjent af danske. Det må her ikke glemmes, at det til rådighed stående preussiske materiel $i$ landsdelen uden al tvivl var disponeret til at transportere tyske stemmeberettigede fra syd ind i landsdelen.

Af det store fællesmødes referat fremgår, at De Danske Statsbaner som sikring af transporterne placerede et hjælpe- og ambulancetog i Vamdrup, der eventuelt kunne indsættes helt ned til Tinglev.

Med baggrund i mødet udsendtes »Særtogsmeddelelse nr. 290«. Heri fandtes alt om afrejsestation, afrejsedato og togbenyttelse for hver enkelt afstemningsberettiget. For at undgå at de preussiske forbindelsestog i forsinkelsestilfælde blev afsendt via Vamdrup hhv. Vedsted/Hvidding uden forbindelse nordfra foreskrev planen, at de danske tog skulle anbringes $100 \%$ rettidigt på grænsestationerne.

Preussiske Statsbaners Eisenbahndirection fastsatte nøje vidererejsen syd for Kongeåen gennem »Fahrplan für die Sonderzüge der aus Dänemark eintreffenden Wähler«, nr. 33 B 15, dateret Altona den 2. februar 1920. Planen består af ikke mindre end 28 tæt beskrevne foliosider, skrevet $i$ hånden og med gotisk skrift. Heri læses, at de oplistede tog syd for Kongeåen bestod af det danske materiel og mandskab nordfra, som videreførtes til Tingleff og Tondern. De uniformerede danske skulle være forsynede med legitimation på dansk og tysk. Til støtte for den tyske togfører skulle alle togene medgives mindst een dansk tysktalende togbetjent, ligesom den på lokomotivet medgivne strækningskendte tyske lokomotivlods skulle kunne støtte sig til $\mathrm{m}$, it een dansk tysktalende lokomotivfører eller fyrbøder. På alle stationer og holdesteder syd for Kongeåen skulle det danske togpersonale "kalde ud « på 
Samlet koreplan for befordring af alle afstemningsberettigede fra $\mid y l-$ land og Fyn til afstemningen $i 1$. zone den 10. februar 1920. Jernbanemuseet.

\section{Plan}

over

Særtog og andre særlige Foranstaltninger

I Anledning af

Befordringen af Væalgere til den

forestaaende Afstemning i Sonderjylland.

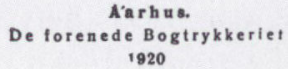

såvel dansk som tysk, herunder også angive de tyske stationsnavne.

Allerede en måned efter kom næste opgave, nemlig tilsvarende togbefordring af de stemmeberettigede til afstemningen den 14. marts 1920 i 2. Zone. Opgaven var af langt mindre omfang, nemlig befordring af ca. 1200 personer fordelt på to særtog via Vamdrup til Flensborg og et fra Vedsted/Hvidding til Niebüll. Den 12. marts kørte to særtog fra Vamdrup gennemkørende til Flensborg og kun standsende i Padborg og Harreslev. Samme dag kørte tilsvarende et særtog fra Vedsted/Hvidding til Niebüll, kun standsende efter behov i Tønder.

I disse planer er »tonen, nationalt, strammet op«. I den danske ud- 
gave læses, at særtogene på den slesvigske strækning (her menes syd for Kongeåen) føres af tyske togførere og der medgives tysk lokomotivlods. Iøvrigt anvendes det danske materiel og personale, men nu forlanges, at den danske lokomotivfører og de danske togbetjente skal være tyskkyndige, samt at een af de danske togbetjente i særlig grad skal opfylde kravet til tysktalende, da pågældende skal fungere som mellemmand og tolk mellem dansk og tysk personale. Planen kræver, at alle afstemningsberettigede skal have forladt 2 . Zone med de fastsatte tog senest den 15. marts, dagen efter afstemningen.

Allerede en god måned senere, og efter at de nye danske chefer og ledere var udsendt, kom næste større danske transportopgave. Det var planlægningen af jernbanetransporten af danske militære enheder til Aabenraa og Tønder. Det skete den 5. maj, hvor danske troppeskibe (statsbanernes Lillebæltsfærger) anløber havne på Sønderjyllands østkyst. Samme dag ankom et troppetog med en dansk infanteristyrke til Tønder, og dagen efter et tog med danske husarer til Aabenraa. Det har ikke været muligt $i$ arkiverne at finde planerne for disse danske troppetog. Men det er nærliggende at antage, at disse transporter er afviklet $\mathbf{i}$ dansk/preussisk samarbejde over samme læst som for afstemningstogene.

\section{Overtagelsen som glippede}

14 dage senere tog situationen en dramatisk drejning. Det skyldtes, at man fra dansk side, trods betydelig tysk modstand, besluttede at indføre den danske møntfod - kronen - i hele 1. Zone med gyldighed fra og med den 20. maj 1920. Natten før, nemlig natten mellem den 19. og 20. maj, ankom en jernbanevogn nordfra til Vamdrup station læsset med danske pengesedler og mønter, der næste dag skulle fordeles til banker, pengeinstitutter m.m. rundt om i hele 1. Zone.

For de tilbageblevne embeds- og tjenestemænd ved de Preussiske Statsbaner ville indførelsen af dansk møntfod medføre en betydeligt forringet levefod. Disse jernbanefunktionærer blev jo fortsat aflønnet i Mark, hvis værdi og købekraft yderligere styrtdykkede efter den 20. maj. Dette affødte omgående trussel om omfattende strejke blandt 1 . Zones tjenstgørende stab af preussiske jernbanefolk af enhver tjenestegren. Virkningen ville omgående blive, at hele landsdelens togtransportsystem blev lammet. Det ville være så meget mere katastrofalt, fordi landevejene var i endnu ringere for- 
fatning end jernbanerne. Mod denne overhængende reelle trussel reagerede chefen for 10 . Trafiksektion i Aabenraa, Juel-Hansen, omgående og kraftigt. Han planlagde straks at gennemføre en selvstændig og hurtig (her og nu) dansk overtagelse af jernbanedriften - ikke mindst for at sikre landsdelens stabilitet og en rimelig nødvendig trafikafvikling. Gennem udsendelse af et fortroligt, skriftligt tjenstligt direktiv, dateret den 17. maj 1920, stilet personligt til den enkelte udsendte danske chef, fik denne instrukser om, hvordan Juel-Hansen ønskede, at den enkelte skulle handle, hvis de bange anelser viste sig begrundede.

Dette fortrolige direktiv er fremstillet på skrivemaskine med et antal blå gennemskrifter. Derfor er det noget ulæseligt. Direktivet til stationsforstander Wissenbach i Tinglev lyder:

»Fortroligt den 17/5 1920

Til samtlige Stationer og Holdepladser i fremtidige 10. Trafiksektion. "Indførelsen af Kronemonten kan muligvis give Anledning til, at det tyske Jernbanepersonale drager bort, hvorefter De Danske Statsbaner antagelig indtil videre overtager Driften af Banerne i 1. Zone. Som Følge heraf vil 10. Trafiksektion være etableret i Vamdrup fra og med Onsdag d. 19. d.s. Kl. 3 Em. Og indtil videre - eventuelt allerede fra i Morgen Tirsdag. Hr. Stationsforstanderen bedes derfor være særdeles agtpågivende de nærmest kommende Dage og, hvis Tyskerne forlader Stationen, overtage denne og pr. Telegram (Jernbane) eller Telefon melde til Insp. 10 Vamdrup station, at dette er sket.

Der må selvfølgelig gåes frem med al mulig Takt og Forsigtighed, og Sammenstød med eventuelt bortdragne tysk Personale må undgås. Såfremt det tyske Personale forlader Stationerne i 1. Zone, vil der snarest fra Vamdrup blive udsendt Arbejdstog med Maskiner, Kul, Personvogne, Inventar, Personel og Rejsende, men da det er af største Interesse at få oplyst, hvad der er blevet tilbage på Stationerne af Lokomotiver, Personvogne og Kul, bedes Stationsforstanderne på Vojens, Rødekro, Tinglev, Haderslev, Aabenraa, Tørsbøl, Vester Sottrup, Skelde, Sønderborg snarest melde telegrafisk til Insp. 10, hvad der er i Behold heraf. Meldingerne må for Maskinernes Vedkommende oplyse Litra, Antal, og om der er tjenstdygtige, for Vognenes vedkommende Klasse og Pladsantal. Eventuelt må oplyses, om og når 
et Tog kan gøres køreklar. Opmærksomheden bedes også fæstet på at søge mulige Forsøg på Hærværk forhindret. Skriftlig Kvittering bedes sendt Insp. 10 Vamdrup.

sign Juel-Hansen«.

Den bebudede udflytning af 10 . Trafiksektion, fra Sonderjylland til Vamdrup, skete omgående. Allerede den 20. maj om morgenen var funktionen etableret i Vamdrup. Herfra sendtes straks de fornødne driftsmidler til Sønderjylland gennem anordning af en række "Arbejdstog".

For at skaffe kontorplads til denne pludselige, midlertidige ledelsesfunktion i Vamdrup, og uafhængig af stationens faste tjenstgørende, såvel danske som preussiske, placerede statsbanerne ekstraordinært en salonvogn på et af stationens sidespor, hvor denne skulle fungere som kontor. Situationens alvor involverede hele statsbanernes topledelse i Jylland/Fyn. I salonvognen samledes chefen for 2 . Distrikt i Aarhus, distriktschef Graae med andre tilkommanderede ledende medarbejdere sammen med den udflyttede sønderjyske ledelse til et fælles »stormøde«. I dag ville vi nok kalde de forsamlede for "Situationens Generalstab«.

Der blev udforligt redegjort for den aktuelle, alvorlige situation. De forsamlede gik straks i gang med at organisere, samle og beordre en større personalestyrke af enhver art samt et større antal lokomotiver, vognstammer og nodvendige forsyninger til Vamdrup station. Alt sammen for med fornøden dansk styrke og med dags varsel at sætte operation "Overtag jernbanedriften i 1. Zone« i værk. Operationen skulle ledes og styres fra salonvognen placeret nord for Kongeåen, og strttes af de allerede på stationerne placerede danske chefer og ledere. De tjenstgørende i denne specielle kontorvogn har i senere beretninger og overleveringer spøgefuldt omtalt vognen som "Marechal Fochs« salonvogn.

Strejken blev imidlertid ikke til noget. Faren drev over, og salonvognen blev lukket og beordret væk. Dens tjenstgørende fra Aabenraa og Tønder vendte tilbage til mere normale forhold.

Mundtlige overleveringer vil vide, at situationen blev opblødt delvis ved, at det fra dansk side blev udvirket, at de preussiske lønninger, indtil den endelige overtagelse, blev udbetalt halvt i Mark halvt i Kroner. Og nu ventede alle spændt på den officielle ordre om at overtage banerne. 


\section{Den sidste svære måned}

For de udsendte statsbanemedarbejdere må den sidste ventetid have været svær at komme igennem. Her midt i maj 1920 prægedes deres daglige tjenestesituation af stor usikkerhed.

Den indenlandske politiske situation med dens aktører har bestemt ikke givet vore udsendte maksimal opbakning, endsige sørget for korrekte, tilforladelige informationer om situationen nord for Kongeåen. Tværtimod.

Regering og rigsdag var dybt optaget af den såkaldte påskekrise, af to hurtige, midlertidige overgangsregeringer, og samtidig truedes landet af generalstrejke iblandet usikkerhed om kongens stilling. Det følgende valg til Rigsdagen resulterede i en ny regering Neergaard, der tiltrådte den 5. maj 1920.

Informationerne hjemmefra fortalte, at Genforeningen trak ud, og den endelige aftale om Versailles-freden var slet ikke endnu forhandlet på plads, endsige underskrevet. Kort og godt, her en måned for den forventede overtagelse af de preussiske statsbaner, bidrog regeringen Neergaard ikke til at afklare de udsendtes situation.

I denne uafklarede atmosfære sivede i begyndelsen af juni 1920 signal om, at den fremtidige grænses fastlæggelse var under opsejling og ville ske i form af en såkaldt notifikation med gyldighed fra og med den 15. juni 1920. Det vil fremgå af nedenstående, at denne »Genforeningsdag « ikke kom til at omfatte statsbanerne i Sønderjylland.

Det overraskende er, at statsbanernes generaldirektorat allerede den 9. juni kl. 19,21 udsender telegrafisk ordre til de tre distrikter om, at alt personel skal være på plads den 14. ds til at overtage driften i 1. Zone fra den 15. juni. Denne sene aftenordre ses ikke omsat i videregivelse af ordrer fra distrikterne til sektioner og stationer.

Trafikinspektør Juel-Hansen har tilsyneladende ikke været kendt med telegramordren og synes at have savnet konkrete informationer og tjenstlige ordrer fra officielt dansk hold. I denne situation, og med lokale rygter om overtagelse i løbet af få dage, tvinges han til at handle. Det sker den 11. juni, hvor Juel-Hansen kører i bil til Flensborg for at drøfte situationen med Director Müller fra Betriebsamt der preussischen Staatsbahnen.

Medvirkende til Juel-Hansens bedømmelse af situationen og nødvendigheden af at handle kan have været, at »Den internationale Kommission« i Flensborg og de militære styrker af engelske og franske trop- 

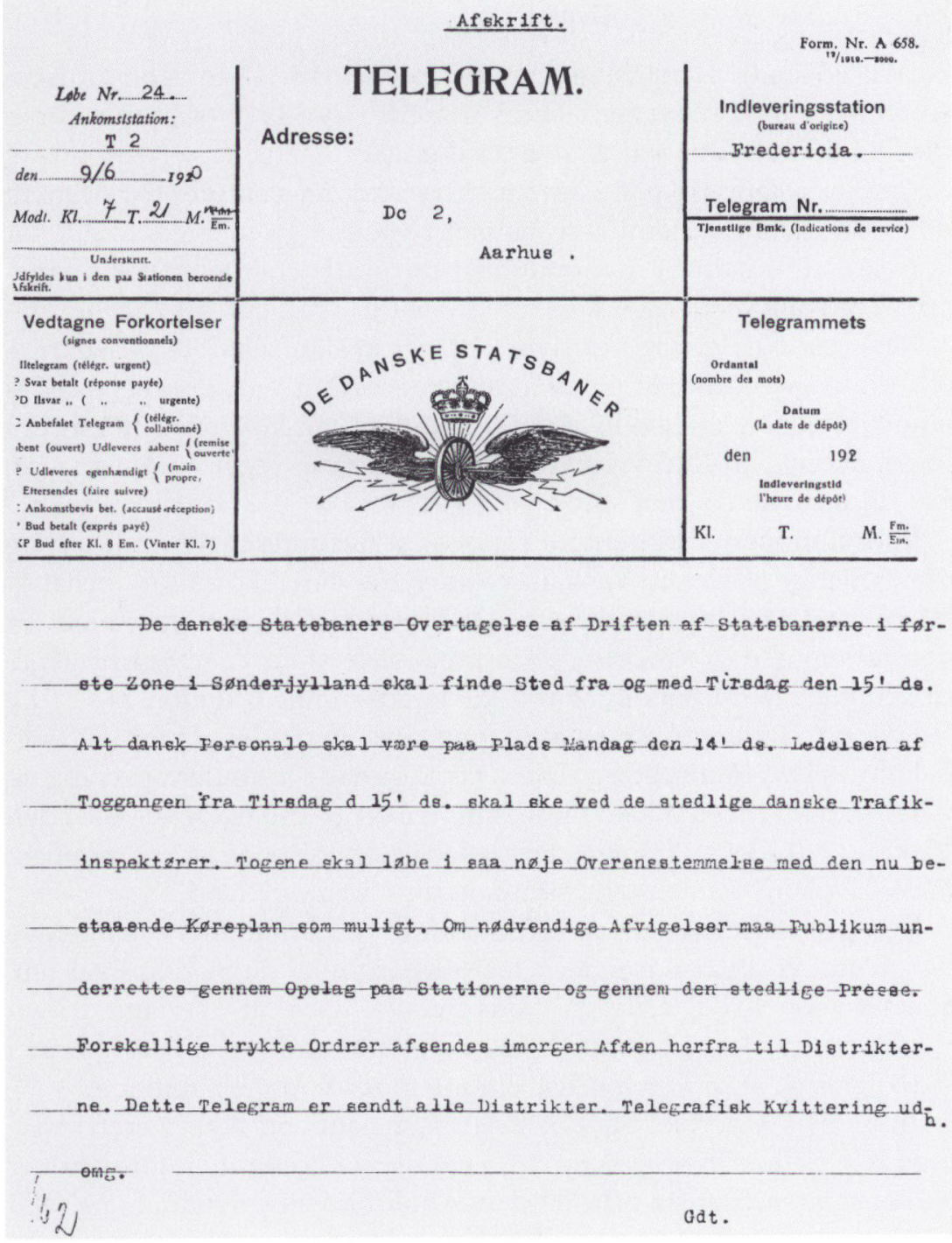

Statsbanernes overraskende telegrafiske ordre til 1., 2. og 3. Distrikt den 9. juni 1920 kl. 19.21 om at vare klar til overtagelse natten 14.-15. juni 1920. Jernbanemuseet.

per stod lige foran opløsning og bortdragning den 16. juni, uden at der var indgået nogen form for juridisk, statsretslig traktat mellem den danske stat og Tyskland om afståelse af 1 . Zone og fastlæggelse af den 
endelige nye statsgrænse mellem de to stater - måske med virkning om blot fire dage. Derfor bilturen til Flensborg den 11. juni.

Det må have været hans mål personligt, og på stedet, at drøfte situationen med kollegaen Director Müller, som var øverste jernbanechef på stedet. Samtidig var han de preussiske baners repræsentant ved »Den internationale Kommission«. Herigennem fik Juel-Hansen en direkte indgangskanal til kommissionen.

På turen til Flensborg medtog Juel-Hansen, som sin sekretær, den unge trafikassistent fra sektionen i Aabenraa, C. Hollesen, senere stationsforstander i Næstved.

Fra mødet beretter Hollesen, at Director Müller oplyste, at han allerede havde udarbejdet et konkret forslag til "Regelung des Betriebes « i de sønderjyske landsdele, ifald overdragelsen skulle finde sted om fire dage. Samtidig var forslaget allerede oversendt til Directionen i Altona med anmodning om tiltrædelse fra preussisk side.

Det var noget helt nyt, og det kom bag på Juel-Hansen. Director Müllers forslag indebar, at kongeriget Danmark nævnte dag overtog den egentlige udførende drift af jernbanerne i 1 . Zone, mens alle fysiske anlæg som bygninger, spor, banelegemer, signal- og sikringsanlæg m.m. først skulle overdrages senere.

På mødet afslog Juel-Hansen, på De Danske Statsbaners vegne, at indgå nogen national bindende aftale med det beskrevne indhold. Direkte fra Flensborg sendte han telegram til Generaldirektoratet om mødets afholdelse, idet han samtidig i telegrammet tilkendegav, at det fra preussisk side forlangte møde var tvingende nødvendigt hurtigst muligt. Derpå forlod Juel-Hansen sammen med sekretæren Flensborg og kørte tilbage til trafiksektionen i Aabenraa.

Dagen efter mødet i Flensborg, nemlig den 12. juni 1920 notificeres - (det vil sige, der sendes en officiel meddelelse til Danmark og Tyskland) - grænsen, og denne ville blive officielt meddelt nævnte lande den 15. juni 1920.

Dagen før Udenrigsministeriet i København modtager denne diplomatiske depeche fra vor ambassadør i Paris, udsendes på landsplan den officielle »Meddelelse fra Generaldirektoratet nr. 115/1920 - dateret København den 10. juni 1920« (dagen efter telegrammet til distrikterne). Herigennem informerer Generaldirektoratet officielt hele Danmark, incl. de udsendte i Sønderjylland, om, at De Danske Statsbaner overtager driften af de preussiske statsbaner i Sønderjylland, fra og med den 15. juni 1920. 
"Meddelelsen « er egentlig udtryk for en bemærkelsesværdig timing! »Meddelelsen «, som jo er departementets officielle, er fremstillet og udsendt dagen før, Juel-Hansen kører til mødet i Flensborg og to dage før, vor ambassadør i Paris sender sin depeche til Udenrigsministeriet og før, at den lovede "Besprechung « mellem landenes statsbaner er afholdt og gennemført. Endvidere har "Meddelelsen" været undervejs $i$ en fortrolig tjenestepost til Juel-Hansen, medens han kører til mødet i Flensborg og tilsyneladende uden at kende til "Meddelelsens « eksistens. Indhold og udsendelse synes ligeledes foretaget uden forudgående følere eller accept $\mathrm{i}$ »Den internationale Kommission«.

Ganske få dage senere måtte statsbanernes Generaldirektorat erkende, at det ikke var muligt at gennemføre overtagelsen som beskrevet allerede den 15. juni. I en ny "Meddelelse nr. 120/1920 « af 16. juni annulleredes overtagelsen. Samtidig meddeltes, at operationen var udskudt til natten mellem den 16. og 17. juni $1920 \mathrm{kl}$. 24.00. Derfor er den 17. juni De Danske Statsbaners officielle Genforeningsdag.

De følgende, nødvendige forhandlinger mellem de preussiske og danske statsbaner om de reelle betingelser for overdragelsen og videreførelse af den praktiske togdrift $\mathrm{i}$ dansk regi blev overladt til embedsværkets decentrale ledelses- og driftsorganer på begge sider af den forventede nye grænse. Det vil i praksis sige til trafikinspektør Juel-Hansen og dennes modstykke i Flensborg Director Müller støttet af begges overordnede bagland.

\section{Trafiksektion flyttes midlertidigt til Tinglev}

I denne nyopståede og helt uafklarede situation beslutter Juel-Hansen ret omgående at flytte sin ledelsesorganisation midlertidigt væk fra Aabenraa til et mere centralt placeret sted. Det blev i første omgang til Tinglev og senere til Rødekro. Ledelsesmæssigt var det af vigtighed for ordreformidling og kommunikation at blive placeret på hovedbanen, på en station med et veludviklet net af kommunikationslinier, primært et velfungerende net af jernbane-telegraf-linier $i$ alle retninger. Af gode grunde kunne "Folkehjem« i Aabenraa ikke leve op til disse krav.

Udflytningen til Tinglev var ikke uden betænkeligheder og frygt for komplikationer. Indtil overtagelsen var stationen betjent af et loyalt, preussisk personale, der som nævnt forholdt sig reserveret 


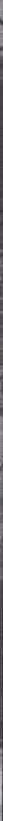

Fællesfotografering på Tinglev station den 17.juni 1920. På billedet ses såvel det tidligere preussiske som det nye danske personale. Endvidere ses personale i den midlertidige, fra Aabenraa udflyttede, 10. Trafiksektion. På forreste række som nr. 2 fra venstre trafikassistent A. P. Larsen, preussisk assistent Petersen, stationsforstander Wissenbach, trafikinspektør Juel-Hansen, preussisk stationsforstander Hansen, trafikkontrollør Stuhlmann, rangerformand Andersen, trafikassistent I. C. Jensen samt trafikinspektør Sahl fra 2. Distrikt $i$ Aarhus. Som nr. 4 i 2. række fra venstre ses trafikassistent Hollesen, som var sekretær for Juel-Hansen på mødet i Flensborg den 15. juni 1920. Foto i Jernbanemuseet.

over for de danske kollegaer. Fagligt og funktionelt betød det, at alle danske tjenstlige tiltag formidlet over jernbanetelegrafen måtte oversættes til tysk og afvikles i samarbejde med den til enhver tid vagthavende preussiske trafikassistent.

For yderligere at forstærke de danskes tilstedeværelse og den nye trafiksektion i Tinglev sendtes i løbet af den 12. juni supplerende administrativt assistance-personale fra distriktskontorerne i Aarhus til Tinglev. Det var lige fra trafik- og køreplansfolk til bane- og maskiningeniører.

Disse mange dygtige danske fagfolk knoklede nu dag og nat $\mathrm{i}$ Tinglev med at fremstille nye køreplaner, opbygge og placere materielmasser og reserver hertil, fremskaffe alle former for driftsmidler, ud- 
arbejde personaleplaner for turskifter og arbejdstilrettelæggelse, så alt kunne være nøje planlagt, klappet og klart, når den endelige ordre til at tage over indløb - forventelig inden for de allernærmeste dage. Af nemhedsgrunde besluttedes, at den eksisterende, stærkt indskrænkede preussiske publikumskøreplan skulle anvendes uændret indtil den 1. juli 1920.

Samtidig arbejdedes på højtryk med at fremstille den første danske publikumskøreplan for Sønderjylland, gyldig fra og med den 1. juli. Den nåede dog først at blive sendt på markedet, efter at trafiksektionen i Tinglev blev flyttet for 2 . gang, nemlig til Rødekro.

Køreplanen blev mødt med en meget hård sønderjysk kritik. Det skyldtes, at kulsituationen i Danmark i forsommeren 1920 var så alvorlig, at der i »det gamle land « måtte ske drastiske køreplansindskrænkninger med inddragelse af mange tog. Det skulle naturligvis også gælde for Sønderjylland. Derfor blev køreplanen pr. 1. juli en ren overgangsplan, stort set lig med den indskrænkede preussiske, som man fra dansk side valgte at videreføre indtil udsendelse den 1. oktober af den normale landsdækkende vinterkøreplan.

Beslutningen mødtes som nævnt med massiv sønderjysk modstand. Efter massivt pres og andragender fra lokale ledende kredse blev beslutningen ændret. Så på trods af stor mangel på kul i Danmark blev der hurtigt sat arbejde $i$ gang med at fremstille en anden, revideret og forbedret køreplan for Sønderjylland gyldig fra og med den 6. september, blot tre uger før det normale danske køreplansskifte.

\section{Det skelsættende Flensborg-møde}

Dette vigtige møde fandt sted den 15. juni 1920. Efter det mislykkede møde i Flensborg den 12. juni har situationen været højspændt. Jernbanemuseets arkiver løfter ikke sløret for, hvem der tog initiativet til at komme videre.

Efter udsendelsen af Generaldirektoratets meddelelse om overtagelse den 15. juni indkaldtes parterne til et stort møde samme dag i Flensborg. Mødet havde til formål endeligt og definitivt at forhandle på plads alle politiske, administrative og driftstekniske forhold $i$ forbindelse med en fuld overdragelse af de Preussiske Statsbaner i 1. Zone til De Danske Statsbaner.

Mødedeltagerne var højt placerede danske og preussiske statsem- 
bedsmænd. Fra dansk side deltog repræsentanter fra Generaldirektoratet, de to jyske Distrikter samt trafikinspektør Juel-Hansen fra Aabenraa, i alt seks personer. Den tyske delegation omfattede ikke mindre end 19 personer. Der var repræsentanter fra den tyske toldetat, fra de preussiske statsbaners Eisenbahndirection i Altona samt, fra Betriebsamt i Flensborg, Director Müller.

Mødets hovedbeslutning blev, at overdragelsen af banerne skulle ske overalt på jernbanestationerne i 1. Zone kl. 24 natten mellem den 16. og 17. juni 1920. Mødets bestemmelser blev nedfældet minutiøst i en større protokol, som dækker ni tætskrevne folioark. Jernbanemuseets arkiver rummer såvel den danske som den tyske version.

Protokollen opdeltes i tre hovedkapitler. Fra de tre hovedafsnit kan nævnes:

at overtagelsesforretningerne opdeles $\mathrm{i}$ tre faser, startende på stationerne natten mellem den 16. og 17. juni $1920 \mathrm{kl} .24$

at De Danske Statsbaner fremover forestod al toggang på de overtagne statsbanestrækninger fra og med morgenstunden den 17. juni

at 1 . fase hurtigt skal afløses af en kortere 2 . fase indtil den endelige

3. fase kunne gennemfores

Derpå en række bestemmelser om den fremtidige toldbehandling,

- muligheden for, at De Danske Statsbaner overtog det tilbageblevne preussiske materiel

- tyske tjenestemænds udflytning af Danmark (boligmangel)

- trafikkens praktiske gennemførelse - hvem kører hvad og hvor?

- tyske krav om direkte "korridor-tog" mellem Hamburg og Sild via Tønder-Højer

- danske krav om et antal direkte tog Tinglev-Flensborg

- regler for dansk overtagelse af tyske tjenestemænd i 1 . Zone

- regler for evt. dansk overtagelse af tyske tjenestemænd i 2 . Zone

- løsning af spørgsmålet »fremtidige grænsestationer«. Her mødte Danmark med kravet om, at der etableres større "fælles grænsestationer « lig de eksisterende i Vamdrup og Vedsted/Hvidding

- gennemgang og oplistning af alle principielle okonomiske forhold omkring drift, takster, fragtsatser, dokumenter, afregningssystemer, bilaterale og mere omfattende jernbaneprocedurer.

Straks efter mødets afslutning fik den danske delegation adgang til, på dansk fra Flensborg, at rundsende resultatet til alle stationerne $\mathrm{i}$ 
1. Zone. Det skete som en »fælles liniedepeche« over det preussiske jernbane-telegraf-net, hvorved alle stationer underrettedes samtidig.

Overleverede iagttagelser fra mødet beretter, at der under de til tider hårde forhandlinger herskede en fredelig og urban tone. Mange af deltagerne kendte hinanden fra andre førte forhandlinger under 1. Verdenskrig.

\section{Overtagelsen}

$\mathrm{Nu}$ fik alle travlt. Fra og med dagen efter kl. 24 skulle alle sort/hvide tyske angivelser fjernes. De rød/hvide farver skulle stråle fra bygninger, opslag, skilte, billetter og lokomotivskorstene. Det officielle DSBDannebrog skulle overalt veje fra stængerne fra den 17. juni $1920 \mathrm{kl}$. 8.

Travlheden på højeste gear gjaldt ikke mindst alle medarbejderne i den midlertidige trafiksektion i Tinglev. Straks efter at depechen var modtaget fra mødet i Flensborg, arbejdedes dag og nat med nye køreplaner og ikke mindst nye tur- og kørelister for mandskab og materiel samt at udfærdige ordrer herom og få disse ordrer kommunikeret og fordelt til landsdelen. En der deltog i ræset har berettet, at han næsten ingen søvn fik, men opvejede tabet ved at spise konstant.

Alt skulle køres på plads, så toggangen kunne påbegyndes smertefrit i dansk regi, så vidt gørligt efter omstændighederne, straks fra morgengry den 17. juni med dagens første danske tog.

Denne hektiske natoperation indskrev sig uudsletteligt i deltagernes erindringer. I årenes løb har mange beskrevet de historiske oplevelser i righoldige samlinger af memoirer, artikler og biografier. Lad os fra denne store kildemasse citere udpluk og enkeltheder med personlige oplevelser fra overdragelsesnatten på nogle af Sønderjyllands største stationer.

På alle landsdelens statsbanestationer mødtes det udpegede danske mandskab i fuld dansk jernbaneuniform med de stedlige preussiske kolleger. Sammen gennemførte de stationernes overleveringsforretninger, og danskerne forberedte morgenens første danske toggang. På langt de fleste stationer startede man med en fælles "personalefotografering " som en erindring fra begivenheden. Sådanne fotografier kender Jernbanemuseet fra flere stationer som Sønderborg, Rødekro, Haderslev, Padborg og andre. Lokalarkiver rundt om i Sønderjylland rummer sikkert andre. 


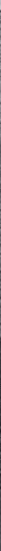

Overleveringsbillede fra Aabenraa station den 16. juni 1920. Midt for i forreste række den afgående preussiske og den tiltrædende danske stationsforstander, O.J.L. Schmidt. Damerne i forreste række er antagelig kontorister fra 10. Trafiksektion. Foto i Jernbanemuseet.

Fra Sonderborg station er overleveret, at præcis kl. 24 natten mellem 16. og 17. juni afleverede den gamle preussiske stationsforstander, Herr Ehlers, stationen til sin danske kollega, stationsforstander Hald, og tog afsked med alle med ordene: "Gute Nacht meine Herren und gute Arbeit“. Herr Ehlers' noble og forstående optræden bidrog til, at overdragelsen her forløb helt gnidningsløst og uden mislyde. Som et yderligere farverigt element $i$ overdragelsen afleverede en høj, flot herre i stram skødefrakke med blanke akselstykker og kårde med gehæng sit embede. Det var "Der Bahnmeister Tietgen“, der i galla markerede begivenheden. Herr Ehlers rejste hurtigt efter til Bayern.

Ved overtagelsen fulgte et stort antal bygninger med. Mange af disse var i en stand, der efter dansk standard måtte karakteriseres som elendig. Der var almindelig enighed om, at flere stationer snarest skulle erstattes af nye og mere hensigtsmæssige i dansk arkitektur. Men der kom til at gå årtier.

En inspektionskomité af de højeste embedsmænd fra generaldirektoratet besøgte straks efter overtagelsen bl.a. også Sønderborg station. 


\section{Gonderburg}
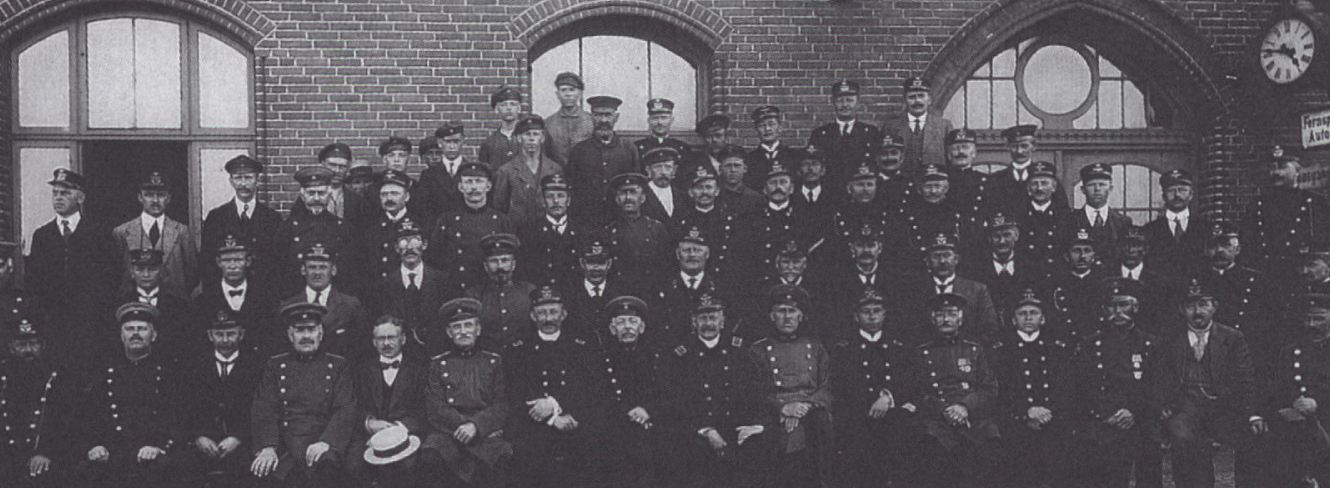

Sønderborg station. Fælles fotografering den 16. juni 1920. Midt for, forreste række fra venstre, trafikkontrollor Lindhardt, preussisk stationsforstander Ehlers, stationsforstander I. A. Hald fulgt af Bahnmeister Tietgen. Iøvrigt det samlede preussiske og danske personale. Foto i Jernbanemuseet.

Det besluttedes, at der snarest skulle tages fat på en større ombygning. Bortset fra de mest nødvendige reparationer, maling, rengøring og oppudsning, skete der intet.

Og dog - ikke længe efter ankom til Sønderborg station materialer og et stort stillads, som blev rejst foran hovedbygningen mod perronen. Der gisnedes om, at nu skulle der bygges et perrontag. Ak nejdet var det gamle preussiske navneskilt "Sonderburg ", malet på selve muren i sort på hvid bund, man ville fjerne, skønt det straks natten 16. til 17. juni var blevet skjult af et flot, nyt dansk stationsskilt med "Sønderborg « $\mathrm{i}$ røde farver på hvid bund. I stedet for at skrabe bogstaverne til det sorte "Sonderburg" bort, blev hver enkelt mursten omhyggeligt hugget ud af muren, vendt, og muret ind igen med den umalede bagside udad. En helt speciel dansk renovering.

Læseren vil nu sikkert spændt vente på, hvordan det så gik stationsforstander Wissenbach i Tinglev?

Beretningerne fra denne nat $\mathrm{i}$ Tinglev fortæller, at den preussiske stationsforstander Hansen denne aften havde låst sig inde på sit kon- 
Chefskiftet på Sønderborg station den 16. juni 1920. Fra venstre Bahnmeister Tietgen, trafikkontrollor Lindhardt, stationsforstander Ehlers og stationsforstander I. A. Hald. Foto $i$ Jernbanemuseet.

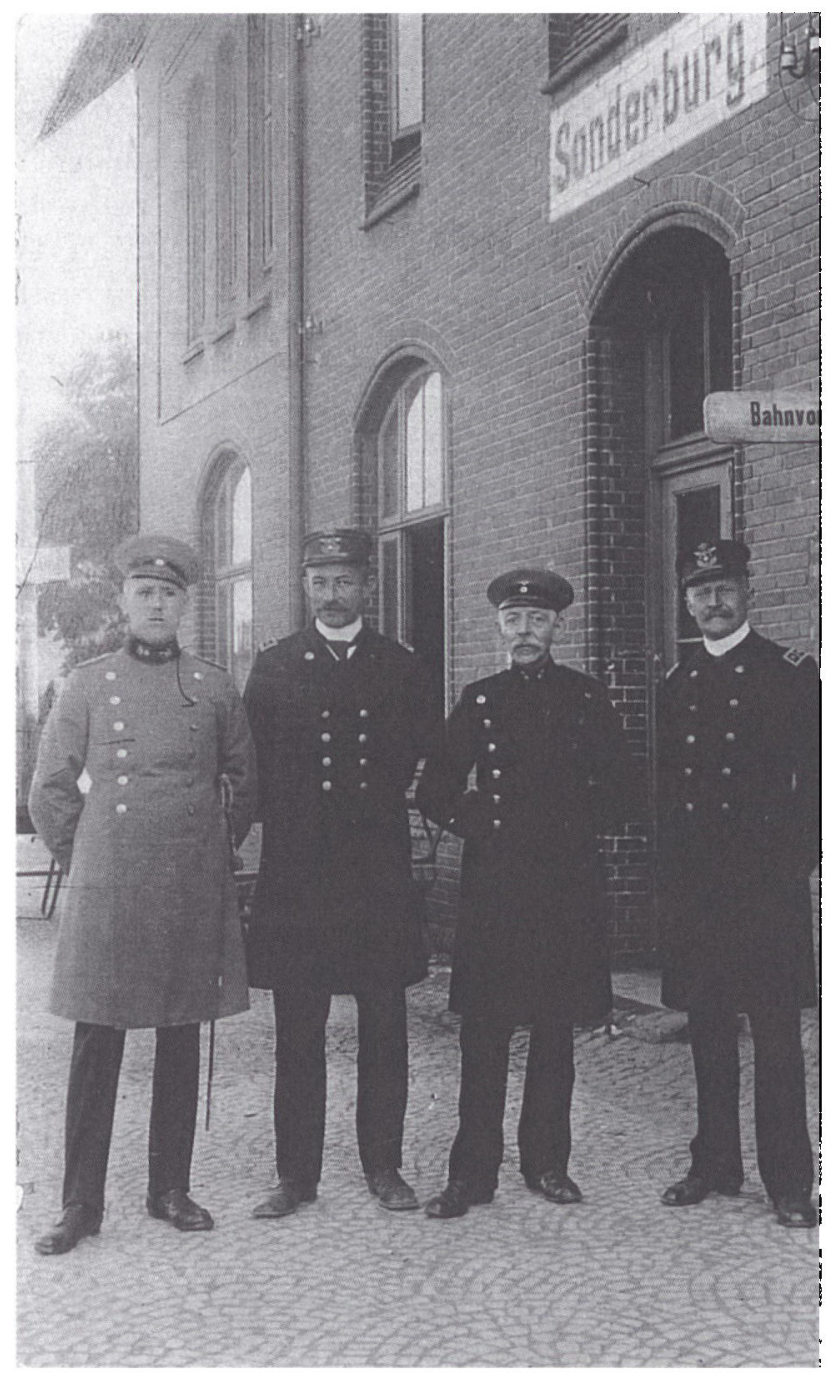

tor. Da Tinglev stationsur faldt i slag kl. 24, åbnedes kontordøren med ordene (i oversættelse): "Mine herrer - klokken er slået 12 - skal vi begynde på overleveringen «.

"Overleveringspapiret" er en dansk formular fremstillet specielt til opgaven. Det oplister den eksisterende kassebeholdning i Mark og Pfennig. Man læser, at formularen er udfyldt nøjagtig den 16. juni kl. 24 nat, og at den pågældende stationsforstander Hansen har supple- 
ret den fortrykte danske tekst med egne tilføjelser på tysk: "Die Obereinstimmung mit meinem für die deutsche Bahn aufgestellen Abschluss bescheinigt.

Tinglev, 17.6.1920 - Hansen - Bahnhofsvorsteher «.

Formularen er underskrevet af såvel Hansen som Wissenbach. Hansens grundighed fremgår yderligere af en ham udfærdiget beholdningsliste over forskellige mængder af uvæsentlige driftsmidler, der af ham blev overdraget dansk statsbaneforvaltning.

I Haderslev gennemførtes overleveringsforretningerne i afslappet stil, ja næsten $\mathrm{i}$ en kammeratlig ånd og tone, som var helt $\mathrm{i}$ overensstemmelse med bedste danske traditioner og skikke. Efter opfordring af den afgående preussiske stationsforstander, Herr Rademacher, indledtes med fælles personalefotografering. Derpå gik mandskabet fra begge baneselskaber på med krum hals under ledelse af såvel den preussiske som den nye, danske stationsforstander, J. J. Høgdal, som var forflyttet fra Vedsted/Hvidding station, så Haderslev station, inden morgensolen brød frem, kunne fremstå $\mathbf{i}$ rød/hvide danske farver.

Umiddelbart efter det historiske øjeblik kl. 24 nat, og efter veludført indsats, inviterede den nye danske stationschef alle sine egne og de afgående preussiske medarbejdere med chef på en bid brød og en dram i stationens ventesal. Ved bordet takkede J. J. Høgdal i jævne ord for det forløbne, korrekte og venlige problemfrie samarbejde med de preussiske kolleger. Den afgående preussiske stationsforstander takkede til gengæld bevæget sine danske fagfæller og bragte sin egen og hele det preussiske personales tak for den danske optræden og hensyntagen i den forløbne tid fra den 21. april til den 16. juni kl. 24. Altsammen smertefrit og $\mathrm{i}$ god overensstemmelse med dansk tradition.

Men - ak - vogt dig for dine egne. Nu havde det lemlæstede Danmark i 56 år efter 1864 slidt, lidt og kæmpet for, at den tabte datter trygt kunne vende hjem i familiens favn - uden smålig skelen til ussel mammon. Her i Haderslev blev den beskedne regning på lidt smørrebrød og en enkelt eller to til halsen, en udgift som havde bidraget til en helt igennem værdig og smertefri afståelse, pludselig et problem $\mathrm{i}$ statens regnskab - ja tænk - hele $70 \mathrm{kr}$. Statsbanernes centrale ledelse nægtede simpelt hen at anvise stationsforstander J. J. Hogdal udgiften med den begrundelse, at »Statsbanerne savnede hjemmel hertil«. Det lugter af Janteloven. Man må give afdøde forfatter Palle Lauring ret, 


\section{Hadersleben (Schleswig.)}

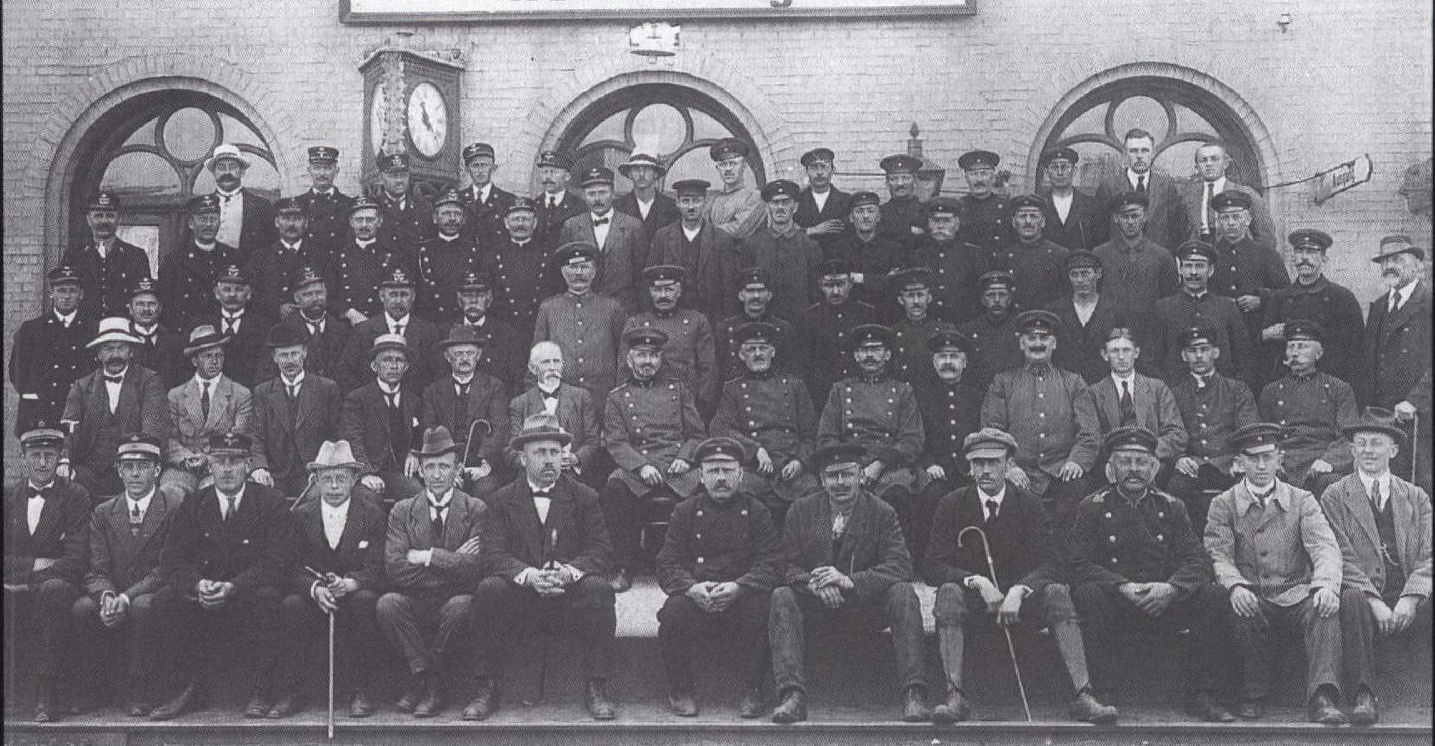

Haderslev station. Fælles personalefotografering den 16. juni 1920. Det ses, at danskerne generelt er korrekt pakklædte, nemlig $i$ civilt antræk. I anden række midt for med bart hoved stationsforstander J. J. Høgdal og den preussiske stationsforstander Rademacher. Foto i Jernbanemuseet.

når han sammenligner os danske med en lokal Brugsforening. Hvem der $i$ sidste ende betalte regningen, det fortaber sig i Genforeningens mere tvivlsomme tåger.

Måske var det et tilsvarende udslag af største sparsommelighed i dansk offentlig regi, at Tinglev stations nye stationsforstander, straks efter overtagelsen den 17. juni om morgenen, lod stationens ældre, tyske sort/hvidstribede flagstang nedtage for at male den over med en god spand hvid dansk maling.

Det skulle han nok ikke have gjort - for sligt var nærmest sprængstof for Tinglevs dansksindede. Hurtigt fik Wissenbach en alvorlig henvendelse fra byens og egnens danske foreninger, der højlydt gav udtryk for, "at en gang maling gjorde det ikke - på den stang kunne DANNEBROG ikke hejses«. Hurtigt måtte der skaffes en helt frisk, ny dansk flagstang til Tinglev station.

Hvordan det gik med regningen på den flagstang? - ja - det forta- 
ber sig også i genforenings-tågen. I grunden fornemmer man tydeligt »de små danske sko«.

\section{Genforeningstog}

Det nye, danske statsbanepersonales første store ilddåb blev opgaven med at planlægge, gennemføre og afvikle de utallige jernbane-trafikale tiltag $\mathrm{i}$ forbindelse med de omfattende Genforenings-festligheder. Til at løse den opgave arrangerede De Danske Statsbaner store ekstraordinære jernbanetransporter fra hele landet til og fra Taps, Haderslev, Aabenraa og Sønderborg samt en række lokale ekstratog i Sønderjylland.

Foruden placering af et utal tjenstgørende personer, heste, automobiler, hestekøretøjer med tilhørende seletøjer, skulle hele regeringen, de mange officielle gæster, hele den Kgl. Livgarde med mandskab og udstyr, og ikke mindst enkedronning Louise sammen med mange lokale sønderjyder befordres til og fra festlighederne den 11. juli 1920 på Dybbøl.

Hele den nødvendige fysiske ramme af heste, automobiler, køretøjer af enhver art samt mandskab hertil hentedes den 8. og 9. juli dels i den kgl. staldetat i Kobenhavn, dels i de jyske garnisonsbyer Viborg, Randers og Aarhus.

De meget omfattende transporter til festlighederne den 10 . juli ved Christiansfeld, i Haderslev og i Aabenraa, samt den 11. juli på Dybbøl Skanse afvikledes på basis af tillysning af en række særtog. Planerne udsendte statsbanerne så sent som den 8. juli. Allerede samme aften afgik fra Københavns Hovedbanegaard et større tog med 18 vogne til Sønderjylland. Toget var sammensat af tre personvogne, seks godsvogne med heste, tre åbne godsvogne med automobiler, fire åbne godsvogne med de øvrige køretøjer samt to vogne læsset med seletøjer og andet udstyr. Bestemmelsesstationen var i første omgang Kolding, hvortil toget ankom dagen efter kl. 12.30.

Her blev toget delt i to mindre tog. Den mindste del, syv vogne, kørtes ad privatbanen, Kolding Sydbaner, til Taps station nær Christiansfeld. Inden afgangen fra Kolding var toget suppleret med en lukket godsvogn med fem heste fra Jylland, nemlig tre fra Randers og to fra Viborg. Blandt de jyske heste fandtes den berømte "hvide hest«, som kom fra Visborggaard nord for Randers.

Samme dag kørte togets største del videre fra Kolding kl. 19.51 via 
Vamdrup-Vojens til Haderslev. Inden afgangen fra Kolding fik det tog indrangeret yderligere to vogne med heste fra Jylland, nemlig tre fra Aarhus og fire heste fra Viborg. Alle de jyske heste befordredes i specielle, lukkede, luksusagtige godsvogne, der var indrettet til kostbare heste. De indvendige vognender og sidevægge samt vognenes særlige hestebomme var polstrede, og hver vogn havde plads til 6 heste foruden et antal hestepassere.

For at tilsikre en rettidig befordring af især hestevognene til Haderslev, udsendte statsbaneledelsen for Jylland følgende, usædvanlige, strenge interne ordre: »Det er af yderste Vigtighed, at Hestene befordres som planlagt, da de skal benyttes til Genforeningsfestlighederne. Såfremt Forbindelsen i Vojens mellem de fastsatte Tog glipper, skal Hestene udlades i Vojens«. Det er mere end nærliggende at antage, at der blandt de særligt overvågede også fandtes den hest, som kongen blev sparket af efter højtideligheden i Tyrstrup Kirke. Efter at festlighederne $\mathrm{i}$ forbindelse med ridtet over grænsen var slut, returnerede toget i Taps "med indhold " til Kolding, hvorfra det omgående blev videredirigeret til Aabenraa. Tilsvarende kørte toget $i$ Haderslev, efter at festen der var tilendebragt, videre til Sønderborg til anvendelse $\mathrm{i}$ forbindelse med festen på Dybbøl den 11. juli 1920.

For at kunne dække behovet for transport til den store nationale festlighed på Dybbøl den 11. juli udsendte statsbanerne en landsdækkende bogtrykt køreplan med angivelse af de mange ekstratog og de dertil knyttede rækker af særlige foranstaltninger. Heri findes planerne for:

- regeringens særtog

- særtoget til regeringens 300 særligt indbudte gæster

- samt - ikke mindst - enkedronning Louises tog med egen salonvogn.

Alle skulle befordres fra København til Sønderborg og tilbage. Enkedronningen sågar frem og tilbage $i$ nattog med overnatning $i$ salonvognen, såvel på ud- som på hjemturen. Foruden en række lokale særtog indeholdt planen et særtog til den Kgl. Livgarde, i alt 15 vogne med 36 officerer og 350 gardere samt yderligere to vogne med gardens bagage og to med gardens egne heste.

Det er interessant, at planen ikke indeholder køreplaner for gæsterne fra Aabenraa til Dybbøl den 11. juli. Forklaringen ligger i, at dampfærgen »Fyn«, fra Lillebæltsoverfarten, var taget ud af regelmæssig 


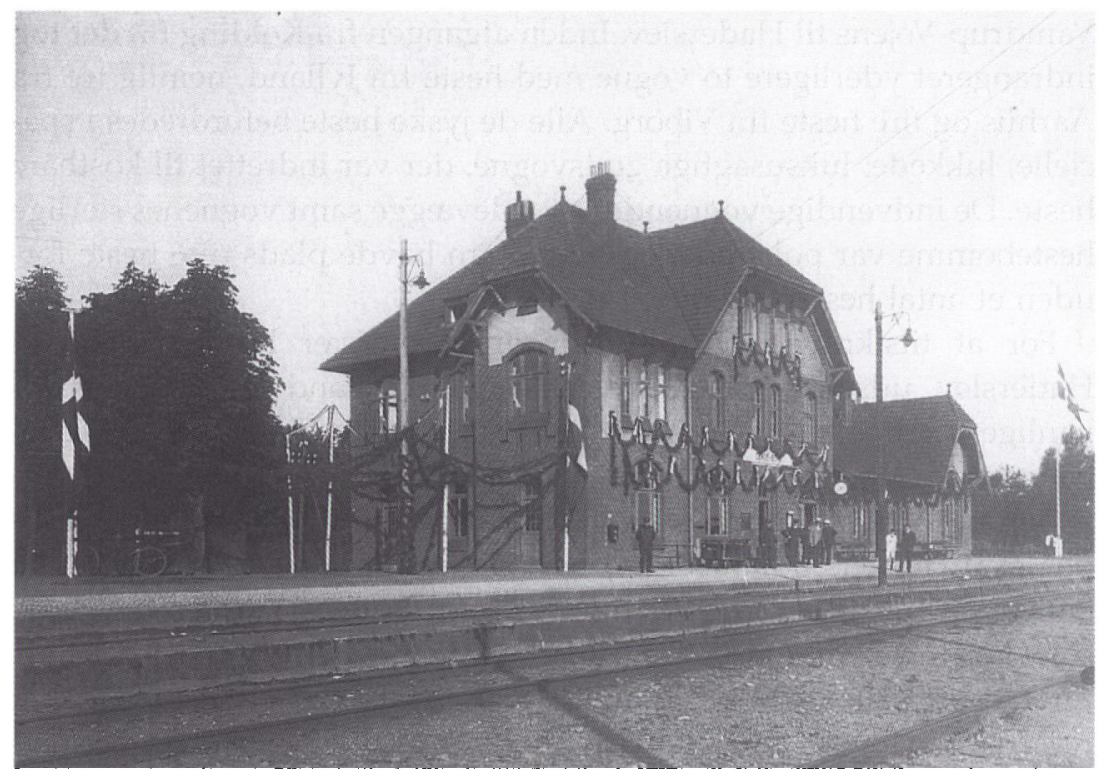

Sønderborg station tidlig morgen den 11. juli 1920 festligt smykket med blomsterguilander som optakt til dagens store nationale fest på Dybbol. Foto $i$ Jernbanemuseet.

drift i dagene 9.-12. juli 1920. I den periode anvendtes færgen til transporter i sønderjyske farvande, og den 11. juli sejlede den med festdeltagere fra Aabenraa til folkefesten på Dybbøl og tilbage.

På dagen oplevede Sønderborg station sit klimaks som midtpunkt i trafikale begivenheder pyntet med blomsterprydede guirlander. Præcis kl. 8 kom en spejdertrop med trommer og hornmusik for at højtideligholde hejsningen af flaget. Stationsforstander og personale var i galla fra morgenstunden, parate til indsats. Trafikinspektør JuelHansen var i dagens anledning residerende i Sønderborg. Derpå ventede alle på de mange ekstratog. Især toget med enkedronningen, som skulle modtages af kongen på perronens røde løber.

Da de tusindvis af besøgende efter festen skulle hjem igen, var hele arrangementet truet af det helt store kaos. Festdeltagerne kom fra det ganske land - alle på enkeltbillet til Sønderborg. På den tid fandtes begrebet »returbillet« ikke i Danmark. Det betød, at den store skare af besøgende skulle købe ny billet til hjemrejsen. Alt tegnede til det helt store sammenbrud. Et lille, udvendigt hjælpe-billetsalg og hovedbilletsalget blokeredes snart af en stormflod af mennesker. Alt disponibelt personale blev aktiveret og, støttet af et antal tilkaldte politibe- 


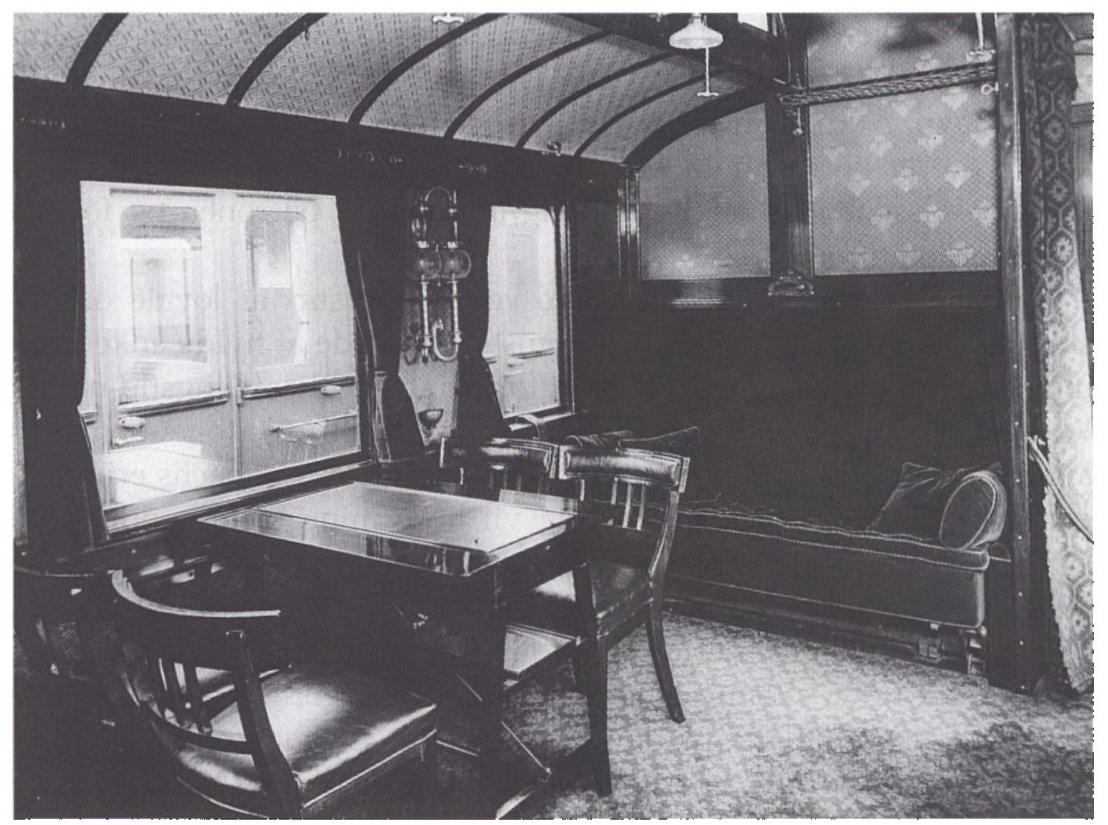

Statsbanernes salonvogn nr. 9, bygget $i$ 1902, anvendt af enkedronning Louise på rejsen København-Sønderborg-Kobenhavn $i$ anledning af festlighederne den 11. juli 1920 på Dybbøl. Foto i Jernbanemuseet.

tjente, blev der sat system i sagerne. Der formeredes endeløse køer, så billetsalget kunne afvikles nogenlunde velordnet, styret og rimelig roligt.

Til enkedronning Louises eget salon-særtog knytter sig to helt specielle, til dels rørende, historier. Enkedronningen havde ønsket personligt at være til stede og deltage i festen på Dybbøl. Og det skete $\mathrm{i}$ eget særtog. Foruden "salonvognen « bestod »Dronningetoget" af en vogn med personlige ledsagere, en vogn med dronningens bagage samt en vogn med tienstlige, faglige ledsagere fra bl.a. statsbanerne.

Toget forlod København natten mellem den 10. og 11. juli og ankom til Sønderborg den 11. kl. 10 - med en ganske lille forsinkelse. For at skaffe enkedronningen mest mulig nattero undervejs, indeholdt togets køreplan en ordre om, at hastigheden over Fyn ikke måtte overskride $45 \mathrm{~km} / \mathrm{t}$, og at toget, efter ankomsten $\mathrm{kl}$. 2.17 nat i Vamdrup, skulle holde stille nogle timer, hvor det placeredes på sporterrænets roligste hjørne, indtil det skulle fortsætte kl. 5.55 morgen til Sønderborg. 
Efter at folkefesten var slut på Dybbøl, rejste enkedronningen samme dags aften, natten mellem den 11. og 12. juli, tilbage i særtoget til København. Af driftsmæssige hensyn i Sønderjylland skulle toget sen aften gøre et kort ophold på Tinglev station. Som nyudnævnt chef var det Wissenbachs pligt personlig at være på perronen og forestå togets ekspedition.

Da toget kørte ind til perronen, var denne sort af loyale dansksindede sønderjyder, som, med blomster, onskede at hylde enkedronningen og udtrykke deres tak. Kort før den fastsatte afgangstid udbad Wissenbach sig enkedronningens tilladelse til at give toget signal til afgang. Svaret fra enkedronningen lød - ifølge Wissenbachs erindringer: "Nej! Stationsforstander, - jeg vil høre mine kære sønderjyder synge "Jeg elsker de grønne Lunde", og jeg vil høre alle versene«.

Efter afsyngningen af alle versene blev der givet signal til afgang, og enkedronningens særtog gled langsomt ud fra Tinglev station, nordpå, ud i den skønneste sommernat, under endeløs jubel fra alle de tilstedeværende, der fik et minde for livet. Oplevelsen gav en togforsinkelse på 13 min., som forlængst må være tilgivet Wissenbach.

Foruden disse mange specielle ekstratog var landsdelens normale persontog forstærket til yderste grænse. At afvikle denne efter forholdene enorme trafik på en enkeltsporet bane, med små stationer og korte side- og depotspor, var en kæmpeopgave, en sand ilddåb. Enhver ledig stump spor på alle landsdelens stationer var belagt med driftsmateriel.

I tiden op under genforenings-festlighederne var vore "midlertidige trafiksektionsfolk“ i Tinglev, af pladshensyn, flyttet endnu en gang. Denne gang den 28. juni til Rødekro, hvor vore sektionsfolk fik "kontorer i et pakrum eller lign. $i$ stationens nordende under meget primitive forhold. Fra disse lokaler lededes "genforenings-slaget $\ll$. Opholdet i Rødekro varede til den 23. juli, hvor sektionens stab af medarbejdere flyttede ind i det endelige domicil, Store Pottergade nr. 6 i Aabenraa.

Men inden da oplevedes en meget tilspidset situation, og det under gennemførelsen af transporterne $i$ anledning af genforenings-festlighederne. Fra Padborg station indløb en tjenstlig "haster-melding" gående ud på, at det preussiske lokomotivpersonale, som i første overleveringsfase skulle fremføre alle tog mellem Flensborg og Vamdrup, $\mathrm{nu}, \mathrm{i}$ forbindelse med de mange danske festligheder, nægtede at køre godstogene længere end til og fra den nye danske grænsestation, Pad- 
borg. Derfor måtte sektions-folkene i Rødekro, midt under festlighederne, hurtigt og effektivt gribe ind for at få situationen under kontrol. Omgående beordredes danske lokomotiver med tilhørende dansk lokomotiv-mandskab fra Fredericia og Vamdrup til Padborg, hvor de forblev indtil videre.

Men det var bestemt ikke uden problemer. For dér var der jo stort set kun en bar mark.

\section{»Paddeborg «, Danmarks nye grænsestation}

Et helt overvældende problem for trafikinspektør Juel-Hansen og mandskabet i Store Pottergade var at få den lille og ubetydelige station Paddeborg til at fungere som grænsestation på den sønderjyske østlige hovedbane. I en tjenstlig indberetning dateret den 25 . januar 1920 behandler Juel-Hansen denne "Grænseproblematik".

Om denne skiver Juel-Hansen bl.a.: "Skal der være Skift af Passagerer fra dansk til tysk Tog og omvendt, og skal der være Skift af Lokomotiver på Godstog, så vil det være nødvendigt med Anlæg af nye Sporforbindelser mellem det såkaldte »Tørsbøl-Spor« og et nyanlagt depotspor «. Derudover gør han opmærksom på, at de af Toldvæsenet benyttede, og af statsbanerne anskaffede, såkaldte "Døckerske Pavilloner", en art store filttelte, burde være meget større. Juel-Hansen skriver videre, at dette interimistiske anlæg for told- og paseftersyn næppe vil kunne klare at afvikle den forventede sommertrafik 1920, som grundet forventede lettelser i pas- og grænseforhold skønnes at blive større end i 1919.

I statsbanernes årlige »Driftsberetninger« kan man læse under »Udgifter til Driften «, at der til de rent midlertidige teltpavilloner alene i finansårene 1919/20 og 1920/21 blev anvendt mere end $200.000 \mathrm{kr}$.

Juel-Hansen slutter sin indberetning fra den 25. januar 1920 med denne bemærkning: "Iøvrigt gælder det samme for Paddeborg som for Faarehus, at da man ikke er klar over, hvilke opgaver Paddeborg skal løse i nærmeste fremtid, kan man ikke, (og her menes Trafiksektionen i Aabenraa), stille bestemte forslag «.

Her må det ikke glemmes, at trafiksektionen mødtes med problemer mange andre steder end Paddeborg, og på samme tid. Banelegeme og spor måtte i hele Sonderjylland straks efter genforeningen underkastes gennemgribende eftersyn og renovering. Alene sidebanen til Haderslev fik i den første månedstid nedlagt over 15.000 nye svel- 


\section{PADDEBORC}
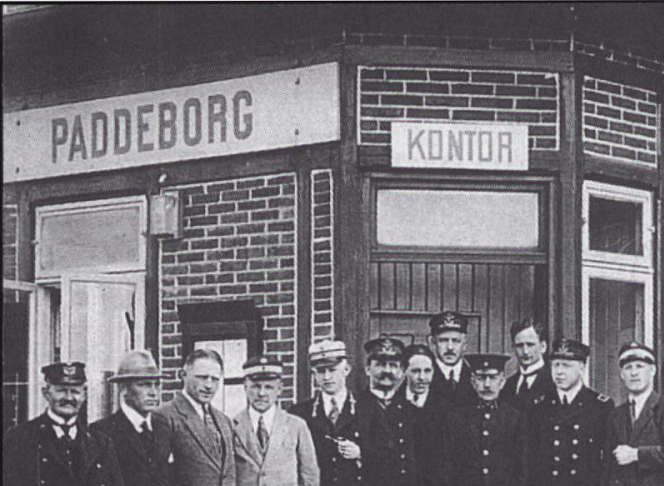
Hertil kommer den grundlæggende danske opfattelse, som blev fremført med styrke på "Flensborg-mødet «, at grænsestationer burde anlægges som fællesstationer lig Vamdrup og Vedsted/Hvidding. Erfaringerne herfra må have begrundet den danske holdning. Resultatet af mødet i Flensborg blev, at Paddeborg station af begge parter blev fastslået som den nye grænsestation.

Overgangen i Paddeborg skulle ske i 3 faser. Den første fase strakte sig fra overtagelsen til den 7 . september, som var ibrugtagningsdagen for den første reelle danske køreplan. Samtidig med udsendelsen af planen indgik Juel-Hansen og Director Müller fra Betriebsamt i Flensborg overenskomst om fælles dansk/tysk jernbanemæssig driftsbetjening af den valgte nye grænsestation, Padborg. Overenskomsten er dateret i Flensborg den 28. august 1920.

2. overleveringsfase blev ganske kort. For Paddeborg og øvrige statsbanestationer blev den endelige driftsform, 3. fase, sat $\mathrm{i}$ værk den 1. oktober, samtidig med lanceringen af den danske vinterkøreplan. Dog fremførtes godstogene mellem Paddeborg og Vamdrup af tysk lokomotiv og personale indtil 1. april 1921.

Tilbage stod nu det uløste driftsproblem på grænsen med den uegnede station, som havde helt utilstrækkelige, fysiske rammer og kapacitet til at kunne løse opgaven.

Det umiddelbare, og helt uafviselige, krav til en betydelig udvidelse af sporpladsen løstes i første omgang ved, at den såkaldte "Tørsbøl-bane" spærredes totalt over strækningen mellem Paddeborg og Nørre Smedeby. Sporet her blev straks inddraget til hensætning af godsvogne. Spærringen kom til at vare til den 1. november 1920.

Et andet grundlæggende problem var, at Paddeborg station slet ikke kunne fungere rent driftsmæssigt, hvis ikke hovedsignalet for indkørsel fra syd blev flyttet »ind i Tyskland«, og stationen herigennem udvidet ind i 2 . Zone. Problemet løstes ved, at der på stedet blev etableret en lokal grænsedragningskommission. Denne fastsatte, at den endelige grænselinie langs banelinien mod syd skulle udformes som en kile ind i Tyskland, $145 \mathrm{~m}$ lang og $50 \mathrm{~m}$ bred, indrammet af grænsestene fra nr. 50 til nr. 53.

I en ny situationsrapport fra Juel-Hansen, dateret den 19. september 1920, behandler han igen bl.a. Paddeborg-problematikken. Om denne skriver han nu, at da han er bekendt med, at 2. Distrikt (hans overordnede) arbejder med udvidelsesplaner, nok så omfattend€, så »skal man her«, ikke beskæftige sig med Paddeborg station. 


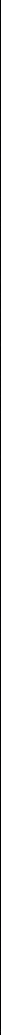

Selv om Den internationale Kommission ved den endelige grænsedragning i terrænet omkring Paddeborg station ikke skar dennes sydende vak fra Danmark, så blev grænselinien trukket så tæt på sporarealet $i$ stationens sydende, at stationen i praksis viste sig ude af stand til at fungere som grænsestation. Det skyldtes især manglende sporkapacitet $i$ sydenden og manglende sikkerhedsafstand til hovedsignalet for togenes indkorsel fra syd. Da Den internationale Kommission forlængst var oplest, blev problemet overladt en "lokal grænseregulerings-kommission«. Denne kom til at bestå af danske og preussiske jernbane-embedsmænd, der klarede opgaven ved at tildele Danmark en u-formet kile sporareal sydpå ind $i$ Tyskland, ca. $150 \times 45$ meter. Grænsestenene $n r .50$ til 53 blev reguleret $i$ overensstemmelse med beslutningen. På billedet ses som $n$ r. tre fra venstre stationsforstander Bandtholtz, der sammen med ovrige (ukendte) kommissionsmedlemmer star midt $i$ arbejdet med den »nye jernbanegrænse«. Foto i Jernbanemuseet.

Denne vurdering har været helt korrekt. Hele den overordnede opgave omkring etablering af den fremtidige, endelige grænsestation krævede politisk beslutning på regeringsplan. Derpå skulle der følge en normal behandling i Rigsdagens to kamre, der kunne vedtage en anlægslov fulgt af en tidkrævende ekspropriationsproces. Når disse faser var overstået, og sagen gået gennem finansudvalget, så skulle et så stort anlægsarbejde optages på særligt kontonummer på de årlige finanslove. Først derpå kunne arbejder udbydes i licitation, inden spaden endeligt sattes $\mathrm{i}$ jorden. Det ville vare flere år. Man fornemmer 
trafikinspektør Juel-Hansens frustration. I det daglige må det have været endog meget svært af få trafikken til at glide over den nye landegrænse.

Først i forbindelse med finansloven for året 1921/22 kom der lidt gang i udviklingen. Det sker som et særligt punkt på tillægsbevillingsloven til finansloven. Her gives der bemyndigelse til at foretage "fornøden ekspropriation" efter reglerne $i$ "Forordningen af 5. Marts 1845 «, for at statsbanerne kunne erhverve de til udvidelse af Padborg station fornødne, ca. 9 ha store arealer. På dette lovgrundlag tegnede statsbanernes daværende chef for baneafdelingen, afdelingschef Flensborg, forslaget til den nye store grænsestation på arealer nord for det gamle stationsanlæg - og tværs over Oksevejen.

Tegningsforslaget er dateret året 1923. I banechefens overordnede tegningsplaner indgik også bygning af to nye viadukter, nyanlæg af amtsvejen (Nørregade til Bovvej), samt elementer i en ny nødvendig byplan for den nye Padborg by i meget større rammer. Endvidere skulle der ske omlægning/forlægning af Tørsbølbanen og sikres arealer til grænsedyrlægen, og til en betydelig udvidelse af eksisterende læsse-sporarealer. Derfor steg det totale arealbehov fra de i loven skitserede ca. 9 til rundt 17 ha.

På basis af oplægget fra De Danske Statsbaner afholdt kommissarius for Jernbanekommissionerne i Jylland, kammerherre Linnemann, i løbet af 1923 en første række »Besigtigelses- og Ekspropriationsforretninger" i Padborg. Disse efterfulgtes af "Taxationsforretninger", som fandt sted i Graasten i efteråret 1923.

Kommissarius' samlede "ekspropriationsforretninger" kom til at strække sig over $i$ alt otte år, inden kommissionen i 1931 var endelig færdig med opgaven. Det havde baggrund i, at et så stort anlægsarbejde havde en række tekniske bi- og følgevirkninger. Der skulle foretages ændringer af eksisterende vandløb, anlægges nye vandafledningssystemer og lignende, delvis helt nye opgaver for Bov Kommune. Derfor måtte der fra og med oktober 1924 og igen i februar 1925 afholdes en supplerende "ekspropriationsforretning ", hvoraf den sidste blev afholdt så sent som i februar 1928, kort før den nye station kunne tages i brug.

Behovet for ekspropriation af de store ekstraarealer modtes med voldsom modstand og kraftige reaktioner fra de lokale lodsejere. Disse tilhørte hovedsagelig den lokale tysksindede bondestand. Antagelig på disses samlede vegne anlagde en enkelt lodsejer sag mod 
den danske stat med påstand om, at ekspropriationen af de ca. ekstra 8 ha savnede lovgrundlag og derfor måtte kendes ugyldig.

Sagsanlægget kom fra en af de største grundejere i Bov kommune, proprietær Heinrich Frederich Peter Sievers. Han ejede hovedparten af de ekstra 8 ha jord, som udgjorde det supplerende eksproprierede areal. I sit sagsanlæg påstod sagsøgeren primært, at arealer til boligformål langs den nye Nørregade i Padborg, hvortil hovedparten af de 8 ha tænktes at medgå, ikke kunne komme ind under de $i$ "Forordningen af 5te Marts 1845 « angivne formål, boliger til banevogtere og vognopsynsmænd, og sekundært iøvrigt ikke kunne anses nødvendige for den egentlige banedrift.

Landsretten optog sagen til doms den 17. oktober 1929. Ministeriet for offentlige Arbejder (statsbanerne) blev frifundet. Herr Sievers appellerede dommen til Højesteret. Dens kendelse forelå den 16. marts 1931 og lød på stadfæstelse af Landsrettens dom - det vil sige - frifindelse af Ministeriet. Dog udtalte Højesteret, at alle sagsomkostninger for Herr Sievers ved begge retsinstanser skulle ophæves.

Det er en ikke uinteressant juridisk krølle fra rettens side. Men uanset dette juridiske kapitel, og længe før sagen var pådømt, skred arbejdet med at anlægge og opbygge den nye store grænsestation støt fremad, og stationen blev hen ad vejen taget i brug etapevis. Den lille og ubetydelige stationsby udviklede sig til en helt ny, stor stationsby med sit eget særpræg. Boligbyggeriet langs Nørregade fik ekstra fart på, den nye amtsvej fra viadukterne ved Padborghus til Bovvej anlagdes og blev byens hovedstrøg samtidig med, at Tørsbølbanen blev forlagt mod nord.

Selve anlægsarbejdet med den nye station startede $\mathrm{i}$ finansåret $1924 / 25$ og var på sit højeste i 1926. Indtil da havde indsatsen været rettet mod midlertidigt at lappe på de alvorligste mangler. Ved afslutningen af finansåret 1927/28, altså forsommeren 1928, var følgende nyanlæg gennemført:

- en hovedbygning plus omfattende sporanlæg

- en ekspeditionsbygning

- en remise med opholdsbygning

- et vandtårn

- et toldpakhus

- et pumpehus

- en toiletbygning 


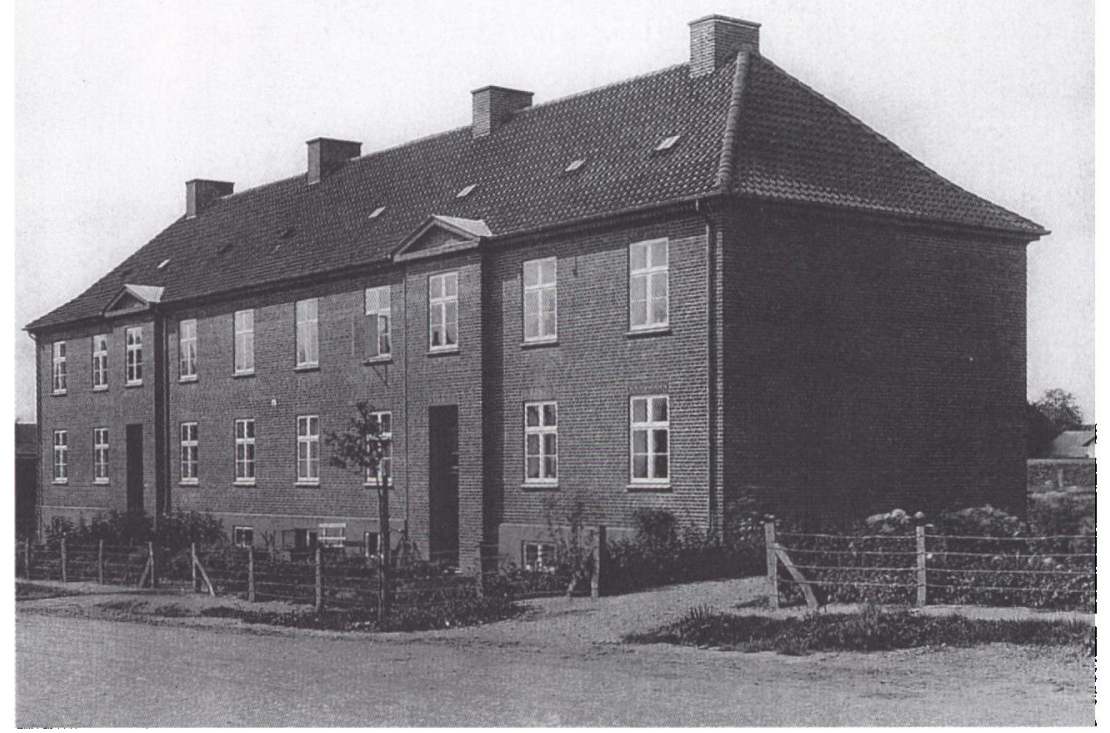

Padborg By. Et af de mange byggerier, der blev opfart i den nye Norregade $i$ Padborg for at skaffe et storre antal tjeneste- og lejeboliger til statsbanernes medarbejdere. Opfort pá de supplerende eksproprierede arealer, hoorom den juridiske kamp blev udkæmpet. Foto i Jernbanemuseet.

Hertil kom de nødvendige tilslutningsarbejder og nyanlæg gennemført af de øvrige etater, organisationer, kommunen og ikke mindst private erhvervsdrivende.

Stationens østlige del var færdigbygget og klar til driftsbrug fra og med den 28. maj 1928. De stadig manglende sporanlæg og bygningsarbejder på stationens vestside blev fuldført i finansåret 1929/30. Det sidste større anlægsarbejde, opførelsen af ny omladehal for stykgods m.m., blev påbegyndt i 1931 .

På det tidspunkt havde "Paddeborg/Padborg«-problematikken varet i 12 år. Midt i perioden skiftede stationen, sammen med Faarehus, officielt navn til Padborg hhv. Faarhus. Det skete i forbindelse med lanceringen af sommerkøreplanen 1924. Der findes ikke nogen egentlig samlet opgørelse over, hvad det hele havde kostet den danske stat i kroner og øre. På de årlige finanslove $\mathrm{i}$ perioden 1919/20 til 1929/30 var der til det egentlige nye, store anlægsarbejde afholdt $i$ alt 3,4 mio. kr. Hertil skal lægges de nødvendige og utallige større og mindre lapperier gennem de samme 10 år. Disse 
udgifter må have været af mindst tilsvarende størrelse. Disse beløb gemmer sig på mange driftskonti i statsbanernes årlige »Driftsberetninger«.

Midt i den mest intense byggeperiode fik stationen og stationsforstander Bandtholz en sand kongelig udfordring. Det skete i november $1925 \mathrm{i}$ en værre snestorm.

Baggrunden var sørgelig. Enkedronningen af Storbritannien, Christian den 9.'s datter Alexandra, var afgået ved døden. Kong Christian den $X$. besluttede at deltage i bisættelsen i England og var rejst med salontog fra København via Fredericia til Esbjerg. På selve rejsedagen blev det et aldeles forrygende uvejr med voldsom snestorm ledsaget af et tungt islag. Det bevirkede, at et betydeligt antal telegrafstænger med ledninger væltede ud over banelinien mellem Lunderskov og Esbjerg, hvor vejret var særlig slemt. I Fredericia måtte statsbanernes ansvarlige togledelse meddele kongen, at det ikke ville være fysisk muligt at gennemføre toget til Esbjerg. I samråd med kongen blev det besluttet, at rejsen i stedet skulle ledes via Padborg.

Herefter blev 10. Trafiksektion i Aabenraa og Padborg station part i sagen. Informationen herom kom, grundet de mange nedfaldne ledninger, ret sent igennem til Aabenraa og Juel-Hansens efterfølger, trafikinspektør Joest. Han nåede lige at drøfte situationen med Bandtholtz i Padborg, inden han ilede til Rodekro for at melde sig i toget til kongen. Her steg kongens humør kendeligt ved meldingen om en helt speciel »kongevogn«, som trafiksektionen og Padborg stations chef ville stille til rådighed for kongens videre rejse. Man anvendte simpelt hen den normale sovevogn Padborg-Aalborg. Vognen var pågældende nat meget tyndt belagt og blev i stedet "omlitreret« til særkongevogn Padborg-Flensborg-Hamburg-???.

Undervejs fra Rødekro mod Padborg spurgte kongen Joest, om det var muligt at skaffe noget mad fra Padborg til fortæring undervejs sydpå. Det bekræftede Joest, som under togopholdet i Tinglev tog kontakt til Bandtholtz og bad ham bestille noget spiseligt i Padborg, evt. noget smørrebrød. Det blev smørrebrød, smurt i hast. Det er mere end sandsynligt, at "Papa Las", (det populære navn på den mangeårige jernbanerestauratør i Padborg), har lavet »klemmerne« lidt mere solide, end kongen var vant til.

Da majestæten senere mødte Joest $i$ anden anledning, truede han spøgende med en løftet pegefinger mod Joest og sagde: "Det var ellers nogle solide klemmer, De skaffede mig fra Padborg “. 
Stationsforstander R. G. E. Bandtholtz, Padborg, $f$. 1873, kom som stationsforstander til Paddeborg $i 1920$ fra Gedser. Blev $i$ stillingen indtil pensioneringen den 1. april 1933. Foto $i$ Jernbanemuseet.

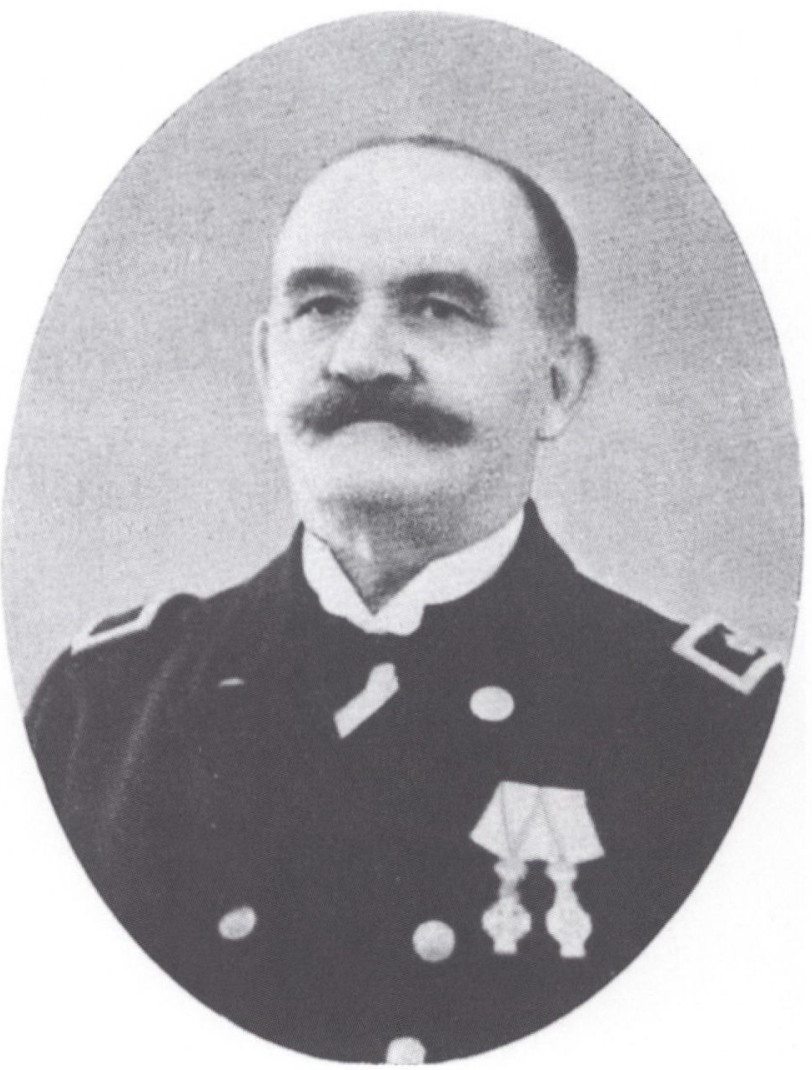

Ja - selv midt i byggerodet og en snestorm - kræver pligten noget af en grænsestation og dens mænd.

Officielt blev den nye Padborg station taget i brug med tog 2907 den 28. maj $1928 \mathrm{kl} .5$ morgen til Lunderskov.

Hermed vendtes et spændende blad i nyere dansk historie. Ikke alene for Sønderjylland, for statsbanerne og Padborg, men i allerhøjeste grad for Bov og omliggende sogne, hvis nyere historie, på godt og ondt, især blev præget af et stort antal uniformerede danske civile og militære embeds- og tjenestemænd samt deres familier. For forretningslivet et sikkerhedsnet, især i krisetider. Uniformen signalerede danskheden og anvendtes derfor også i fritiden. Derigennem satte De Danske Statsbaner den nye store grænsestations egen særprægede kultur på skinner.

Men det er en helt anden historie. 


\section{KILDE- OG LITTERATURLISTE}

Danmarks Jernbanemuseum, diverse arkiver.

Danmarks Jernbaner, 1933, bd 1.

De danske Statsbaner, 1847-1947, Kobenhavn 1947.

Forhandlinger i Rigsdagspartiernes Sønderjyske Udvalg, 1919-1920 s. 109-112, 141,195 og 1479-1482.

Dansk Lokomotiv Tidende, nr. 4 af 16.02.1920.

Hver Dag nr. 19, 1920, side 27.

Verden og Vi, 1920 s. 887.
Erindringer:

Chr. Schmidt, Vor Stand nr. 4, 28.02.1919. Vor Stand, 1921, s. 236, 252 og 268.

Vor Stand den 08.05.1967

Dansk Jernbaneblad nr. 2316, 1942.

Vingehjulet nr. 17 af 09.06.1945.

J. A. Wissenbach, Vingehjulet nr. 4 af 25.11.1955.

J. Esmarch, Jernbanebladet nr. 5-7, 1970.

H. C. Hollesen, Vingehjulet, nr. 28, 1960 s. $326 \mathrm{~mm}$.

Hakon Husted, avisartikel, Flensborg Avis af 08.03.1982. 